\title{
Britain and the Gulf Shaikhdoms, 1820-1971: The Politics of Protection
}

James Onley

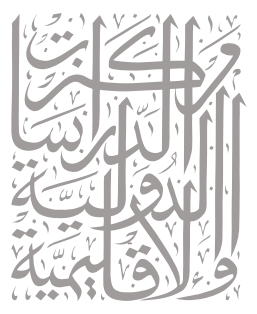

CIRS

CENTER FOR INTERNATIONAL AND REGIONAL STUDIES

GEORGETOWN UNIVERSITY SCHOOL OF FOREIGN SERVICE IN QATAR

(C) 2009 


\title{
Britain and the Gulf Shaikhdoms, 1820-1971: The Politics of Protection
}

\author{
James Onley
}

(C) 2009 Center for International and Regional Studies Georgetown University School of Foreign Service in Qatar

Occasional Paper No. 4 ISSN 2072-5957 


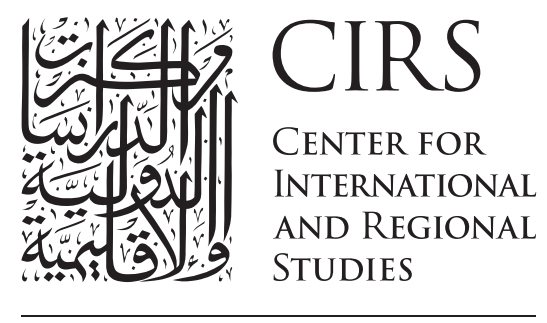

GEORGETOWN UNIVERSITY

SCHOOL OF FOREIGN SERVICE IN QATAR

Established in 2005, the Center for International and Regional Studies at the Georgetown University School of Foreign Service in Qatar is a premier research institute devoted to the academic study of regional and international issues through dialogue and exchange of ideas, research and scholarship, and engagement with national and international scholars, opinion makers, practitioners, and activists.

Guided by the principles of academic excellence, forward vision, and community engagement, the Center's mission revolves around five principal goals:

- To provide a forum for scholarship and research on international and regional affairs

- To encourage in-depth examination and exchange of ideas

- To foster thoughtful dialogue among students, scholars and practitioners of international affairs

- To facilitate the free flow of ideas and knowledge through publishing the products of its research, sponsoring conferences and seminars, and holding workshops designed to explore the complexities of the twenty-first century

- To engage in outreach activities with a wide range of local, regional and international partners.

This publication series is made possible by the generous support of Qatar Foundation for Education, Science and Community Development. 


\title{
Britain and the Gulf Shaikhdoms, 1820-1971: The Politics of Protection
}

\author{
James Onley
}

James Onley is Senior Lecturer in Middle Eastern History at the Institute of Arab and Islamic Studies, University of Exeter and was CIRS Senior Fellow during 2008-2009. He specializes in the history, society, culture, and politics of the Gulf Arab states, and is Director of the Gulf Studies MA and PhD Program at Exeter. He received his DPhil in history from the University of Oxford (2001), where he studied at St. Antony's College. 



\begin{abstract}
This article examines Britain's protection of Kuwait, Bahrain, Qatar, the Trucial States (United Arab Emirates), and Oman during the era of British hegemony in the region: 1820-1971. It argues that Britain's role as guardian of the Persian Gulf, beginning in 1835, was not imposed coercively, that Britain largely conformed to local expectations of a protector's duties and rights, and that its record in Eastern Arabia was far better than its record elsewhere in the Middle East. It begins with an overview of regional insecurity before the Pax Britannica. It then examines why Britain came to defend Eastern Arabia and the advantages and disadvantages that entailed for the local rulers. It explains the legal status of the Gulf shaikhdoms and Oman resulting from their treaties with Britain and their close relationship with the British Empire. It also discusses Britain's post-war attempts to develop these states, the nature of Anglo-American relations in the region, and the growing challenges to Britain's position in Eastern Arabia in the 1950s-60s. It provides a new account of Britain's withdrawal from the Persian Gulf, showing how Britain introduced defense arrangements that remain in place forty years on. It finishes with a reflection on Britain's legacy in the Gulf today.
\end{abstract}

\title{
Acknowledgements
}

This article was written during my Senior Fellowship (2008-2009) at the Center for International and Regional Studies, Georgetown University School of Foreign Service in Qatar. I am most grateful to the Qatar Foundation and Georgetown University for funding my position and to Mehran Kamrava (Director of the CIRS), Naila Sherman (Associate Director of Finance and Administration), Suzi Mirgani, Zahra Babar, Aphrodite Hammad, and Maha Uraidi for their support during that year. For their comments on this article, I would like to thank Mehran Kamrava, J.E. Peterson, Sulayman Khalaf, Larry Potter, Steve Wright, Greg Gause, Gerd Nonneman, Mohammed Ayoob, and Gloria Onley. I am also grateful to Steve Wright for his hospitality and assistance during my stay in Qatar. 



\section{Introduction}

For the rulers of Eastern Arabia, the strongest current running through the history of Anglo-Arab relations in the Persian Gulf during the era of British hegemony (18201971) was the problem of protection. It shaped the world within which the Gulf rulers lived more than any other factor. The popular perception of the British era in the Gulf itself is that British protection was imposed from above, coercively, through gunboat diplomacy. The reality, as this article shows, is that the rulers actively sought British intervention and protection. The involvement they sought was diplomatic (to arbitrate and guarantee peace settlements between rulers), naval (to enforce those settlements and defend their shaikhdoms and subjects from maritime attack), and military (to defend their domains from land attack). In response to these requests, Britain eventually assumed responsibility for the defense of Oman in 1829, the Trucial States (the present-day United Arab Emirates) in 1835, Bahrain in 1861, Kuwait in 1899, and Qatar in 1916. Once Britain accepted the role of protector, it largely conformed to local expectations of a protector's duties and rights, while ensuring the rulers honored their duties and commitments as protégés. This collaborative relationship was the reason for the success and longevity of the Pax Britannica in the Gulf.

British protection eventually led to other forms of involvement, of course. In the late nineteenth and early twentieth centuries, the British assumed control of the rulers' foreign affairs, incorporating the Gulf shaikhdoms and Oman into the British Indian Empire, isolating Eastern Arabia from the outside world. After the First World War, Britain controlled the exploitation of Gulf oil and established airfields linking Britain with its colonies in Asia. After the Second World War, it helped develop these countries into modern states. During the 1950s-60s, Arab nationalists and communists challenged British hegemony in the Gulf domestically and internationally, placing pressure on Britain to leave. But when Britain announced its decision to leave, it did so for domestic political reasons unconnected with the Gulf, against the wishes of the rulers. It left behind a defense structure that remains in place to this day. The sections below investigate these various aspects of British involvement in the Gulf, beginning with the state of Gulf security before the Pax Britannica.

\section{Gulf Security Before the Pax Britannica}

For the rulers of the Gulf shaikhdoms, the protection of their shaikhdoms and dependencies from antagonistic regional powers was an on-going problem. They often lacked sufficient military resources and were forced to seek or accept outside support. To the outside observer at the time and to most academics today, relations between the rulers appear volatile before the Pax Britannica; the only way rulers could safeguard their domains from attack was through their militaries. Competition for scarce resources had produced, as one British official put it, "a condition wherein every man's hand was ever prone to be raised against his neighbour." This impression is deceptive, for there was a diplomatic system at work providing a degree of stability 
and predictability to regional relations and security: a code of conduct observed by most Gulf rulers at that time. When the British became aware of this system and adopted the code of conduct themselves, it became the foundation of the Pax Britannica. $^{2}$

The rulers of Kuwait, Bahrain, Qatar, the Trucial States, and occasionally Muscat, all lacked the means to defend their domains without outside help. If a ruler faced the impending attack of a stronger enemy, therefore, he had little choice but to seek the protection of a regional power (the Ottomans, Persians, Saudis, Omanis, and Qawasim of Sharjah and Ras al-Khaimah) to ward off the threat. These protectors gave guarantees of defense in return for subservience or the relinquishment of some degree of independence. The protégé's payment of tribute symbolized this and had a transforming effect. ${ }^{3}$ The protector regarded his tributary as a part of his own tribe. ${ }^{4}$ Similarly, the protector regarded his tributary's territory as his territory, but with one important distinction. The protector considered such land, especially if it was at some distance from his shaikhdom, to be a "dependency" rather than a part of his shaikhdom. The protector usually left the governing of his dependency to the local ruler or tribal leader who had submitted to his authority. ${ }^{5}$

Custom dictated the amount of tribute a protégé should pay his protector, if he were to pay any at all. ${ }^{6}$ If the parties failed to agree on the amount, they would often enlist a neutral ruler to arbitrate. Tribute was normally paid annually and could take many forms: a fixed sum of money; a share of the annual customs revenue; a share of the agricultural produce (mainly dates); a certain number of horses, camels, etc.; provision of men for military service; and even zakat (Islamic alms that, in the Sunni interpretation, Muslim officials normally collect from Muslim subjects). Tribute was typically imposed as khuwa. In its original form, khuwa was a "brotherhood fee" paid voluntarily by the weak to the strong in return for protection. ${ }^{7}$ The protector became, in effect, his protégé's big brother, with all the responsibilities that entailed.

A ruler's forceful imposition of khuwa as a "protection tax" on another ruler, however, symbolized not brotherly relations but political domination. ${ }^{8}$ Khuwa clothed unequal power relations in a culturally meaningful kinship ideology. ${ }^{9}$ Militarily strong rulers would often threaten to attack weaker rulers with the intention of tribute-collection, not military conquest. The same tactic was employed by those who controlled Arabia's trade routes and imposed tolls (often as khuwa) on those who used them. Tribes also collected khuwa from desert towns and villages within their territory (dira). If the ruler of a shaikhdom, governor of a town, skipper of a ship, or leader of a caravan refused to pay tribute to a would-be attacker, he risked military conquest or raiding. ${ }^{10}$

This tribute system was regulated by the Arabian custom of protection-seeking. The norms and obligations of the protector-protégé relationship provided the rulers with an effective survival strategy in the face of Arabia's ever-shifting power dynamics. The rulers used these norms and obligations in a variety of ways to legitimate and regulate their political relations with regional powers and, in time, with Britain as well. ${ }^{11}$

Personal honor was central to both the politics of protection and regional political 
relations. If someone requests protection, honor demands that protection be given. ${ }^{12}$ The granting of protection is considered an honorable deed, which enhances the reputation of the protector, while refusing protection has the opposite effect. ${ }^{13}$ Once protection is granted, the protégé is "on the honor" of his protector. This law of protection-seeking, known in the upper Gulf as dakhala ("entering" protection) and in the lower Gulf as zabana (refuge-seeking), is a sacred and honored custom throughout Arabia. ${ }^{14}$ In this system of protection, a protégé is answerable to his protector who, in turn, is answerable to the public for the actions of his protégé. If one has a claim against a protégé, he is supposed to go to the protector, not the protégé. ${ }^{15}$ Protégés of rulers - be they individuals, tribes, or other rulers - normally paid tribute to their protector. ${ }^{16}$ The norms and expectations of dakhala and zabana influenced the conduct of the Gulf rulers towards regional powers and, in time, towards Britain as well. ${ }^{17}$

If a ruler was unable to secure, or unwilling to accept, the protection of a regional power, or an alliance with a less powerful ruler, and faced certain defeat in battle against his enemy, he had one last resort. It was acceptable for him to place himself under his enemy's protection as a form of reluctant nominal subservience. This was a political compromise preferable to outright military defeat. If a ruler did this, he became a protégé and was required to pay tribute as a sign of submission and political subordination. Henceforth, the ruler's shaikhdom was considered a dependency of his protector, as discussed above. The ruler became, in effect, a governor who ruled on behalf of his protector. ${ }^{18}$ For powerful rulers and tribes, submissions were often nominal and always temporary, lasting no more than a few years. For weak rulers and tribes, submission involved a greater loss of autonomy and tended to be more permanent, lasting for decades or even generations, as did the tribute payments. All the ruling families of the Gulf today have been the protégés of regional and extraregional powers in the past, including the Saudis and Omanis. In the nineteenth and twentieth centuries, most of them sought British protection.

\section{The Establishment of the Pax Britannica}

The Pax Britannica in the Gulf was established through a series of maritime defense treaties, collectively known as the Maritime Truce, which Britain signed with the rulers of the Trucial States in 1835, Bahrain in 1861, Kuwait in 1899 (de facto), and Qatar in 1916. There is a common perception in the Gulf today that these treaties and the resulting Pax Britannica were imposed from above against the wishes of the Gulf rulers. ${ }^{19}$ The opposite was in fact the case. The rulers actively sought British protection; the Pax could not have been established in the first place without their approval and support. ${ }^{20}$

Britain's relations with the Gulf shaikhdoms and Oman were the responsibility of numerous branches of government over the years. Originally these relations were conducted by diplomats from the British Governments of Bombay and India, overseen by the East India Company (1600-1858) and India Office (1858-1947). After Indian independence in 1947, Anglo-Gulf relations were conducted by diplomats from the 


\section{Foreign Office in London.}

Before the nineteenth century, British interests in the Gulf were limited to three areas: the shipping lanes between Bombay and Basra, connecting India with Britain via Aleppo; the East India Company's trade with Iraq, Iran, and Oman; and the protection of British ships and subjects in the region. ${ }^{21}$ The British had no interests in Eastern Arabia beyond the port of Muscat. All that changed in 1797. From that year onward, maritime toll-levying and raiding by Arabs of the lower Gulf - similar to bedouin practices along desert trade routes - increasingly threatened British Indian shipping. ${ }^{22}$ The British Governments of Bombay and India considered these practices extortion and piracy. They believed the Qawasim (singular Qasimi) — the ruling family of Sharjah, Ras al-Khaimah, and Lingah — to be behind these raids. To stop the raids, the British blockaded a fleet of Qasimi dhows in 1806 and sent naval expeditions in 1809 and 1819 against a number of Qasimi ports. After the second expedition, the British were able to impose an anti-piracy treaty - known as the General Treaty of 1820 - on the Qawasim and all the other rulers and governors of what is now the United Arab Emirates. The Rulers of Bahrain, who wished to avoid maritime toll-paying, were admitted to the Treaty at their request.

The British Government of Bombay created the post of Political Agent for the Lower Persian Gulf, headquartered on Qishm Island in the Strait of Hormuz, to manage British India's relations with these rulers, supervise the enforcement of the General Treaty, and protect British India's ships and subjects in Arabian waters. Two years later, in 1822, the Government transferred this post to Bushire on the southwest Persian coast and amalgamated it with the much older post of Bushire Resident. The new post of Resident in the Persian Gulf - Political Resident in the Persian Gulf (PRPG) after the 1850s - was responsible for Britain's relations with the entire Gulf region. ${ }^{23}$ The Resident's headquarters, known as the Gulf Residency, remained in Bushire until 1946, when it was transferred to Bahrain. The Resident visited the Gulf shaikhdoms and Oman only once a year in the nineteenth century and twice a year in the twentieth. To conduct Britain's diplomatic relations with the Gulf rulers on a daily basis, the Resident maintained subordinate political agents at Muscat (c.1758-1971), Manama (c.1816-1971), Sharjah (1823-1953), Kuwait (1899-1961), Doha (194971), Dubai (1953-71), and Abu Dhabi (1957-71), as well as the Omani enclave of Gwadar in what is now Pakistan (1863-1958). He maintained a second network of agents throughout southern Iran. ${ }^{24}$ The job of the agents was to monitor and protect British interests within their districts, gather intelligence, enforce the terms of the treaties, and cultivate good relations with the rulers. Sir Rupert Hay (Gulf Resident 1941-2, 1946-53) described the agent-ruler relationship this way:

The close personal contact maintained between the Political Agents and the Rulers is an outstanding feature of the British position in the Persian Gulf. They meet each other frequently, and more often socially than for official talks. Possibly the social meetings are more important than the official ones, as a hint dropped here and there in the course of a casual conversation is often more effective than formal advice, and the Rulers, being Arabs, are quick 
to resent any attempt to teach them their business. Usually, the relations between a Ruler and his Political Agent are, outwardly in any case, those of personal friends .... ${ }^{25}$

To support the Resident and his agents in the enforcement of the General Treaty, the Government of Bombay also established a Persian Gulf Squadron in 1821 to patrol the waters of the Gulf. The Gulf Squadron consisted of five to seven shipsof-war in the age of sail and two to four gunboats in the age of steam (from the 1860s onward) ${ }^{26}$ It was commanded by the Senior Naval Officer in the Persian Gulf (SNOPG) and headquartered on Qishm Island (1823-1911) and then Henjam Island (1911-35) in the Strait of Hormuz, and finally at Bahrain at Ras al-Jufair (1935-71).

So desirable was British protection in Eastern Arabia that, shortly after the signing of the General Treaty of 1820 banning "piracy," the principal pearl merchants of Sharjah offered to pay khuwa to the British at the rate of twenty Maria Theresa dollars (forty rupees) per boat if the Persian Gulf Squadron would permanently station a gunboat at the pearl banks to protect their pearling fleets. ${ }^{27}$ Between 1805 and 1861, the Resident received requests for protection from the Gulf rulers no less than ninety-eight times: sixty-four from the Trucial States, twenty-one from Bahrain, twelve from Oman, and one from Kuwait. ${ }^{28}$

Initially, the British Government of Bombay rejected these requests, later they agreed to provide the temporary protection of the Gulf Squadron on a case-by-case basis. The Government responded in this manner because it believed the costs of protection outweighed the benefits in at least seven ways.

First, if it became protector of the Gulf shaikhdoms and Oman, it feared it would be drawn into the unstable and unpredictable affairs of the mainland. Second, it believed a larger naval presence would be necessary to protect the shaikhdoms, with a corresponding drain on the treasury. Third, it believed that British protection would secure the rulers in their positions against all rivals, making them less dependent upon their families and people for support, allowing the rulers to become autocratic and potentially despotic, as had happened in some Indian states under British protection. And despots, the British knew from experience, tended to alienate their subjects, leading to protest, oppression, resistance, and unrest, which ultimately threatened British subjects and interests within that state. Fourth, the Resident would lose political leverage with the Gulf rulers if he switched from a conditional to an unconditional protection policy. Fifth, permanent protection would shoulder the Government with the role of guarantor of the state. Successive Residents were worried that such a role might considerably add to their burden by placing upon them "the onus and responsibility of being the arbiter in every dispute and settlement of endless claims," to use the words of one Gulf Resident, Major James Morrison (1835-7). ${ }^{29}$ Sixth, the huge death toll experienced by the short-lived British garrison in the Gulf (1820-3) from disease and a disastrous expedition in Oman, convinced the Government that it should never station troops in the Gulf again. Thereafter, the most it could offer the shaikhdoms was the protection of its Gulf Squadron, limited to the range of its naval cannon. And, seventh, the maritime protection of the island of Bahrain would 
equate to full protection. This was problematic, since the Sultan of Muscat, the Amir of Najd and Hasa, the Persian Prince-Governor of Fars, and the Ottoman Governor of Baghdad all claimed Bahrain as a dependency and had attempted to subjugate it at one time or another. Successive Residents feared, rightly, that the protection of Bahrain would bring Britain into conflict with these regional powers.

Possible misunderstandings about what the Gulf rulers were asking of the Resident might have also contributed to the Government's reluctance to assume a protective role in the Persian Gulf. The British concept of protection relied on the protector's ability to defend his protégé physically and bring an attacker to justice. As a deterrent to attack, it relied solely on a would-be attacker's respect for the firepower of the protector. The Arabian concept relied additionally on a protégé's respect for the honor of his protector, as explained above, thus inhibiting enemies who shared the same protector from attacking each other. It also relied on the protector's secondary roles of mediator, arbiter, and guarantor of settlements to provide a peaceful channel for would-be attackers to settle their differences with the protégé. It seems that early Residents either misunderstood or rejected the duties of this role in which Gulf rulers were trying to cast them. Many rulers were frustrated by the failure of successive Residents to live up to these expectations. Early Residents for instance were usually willing to mediate between rulers, but they refused to act as guarantor of the settlements reached. Settlement negotiations usually broke down as a result, as Lieutenant Arnold Kemball (Assistant Resident 1841-52, Resident 1852-5) observed in 1844: "Experience has shown that the most solemn engagements between these chieftains ..., formed without the guarantee of the Government, are no security whatever for the maintenance of peace." "[They] deem the guarantee of the British to any sort of arrangement a sine qua non." "Attempts have been made to induce the several chiefs to enter into a mutual agreement among themselves, without British guarantee ...; but these have ever been rendered nugatory by Arab pride and sense of honour." ${ }^{30}$ The greatest frustration, of course, came from the early Residents' routine rejection of the rulers' requests for protection in the first place.

The Government made its first, hesitant, commitment to extend the protection of its Gulf Squadron to a Gulf ruler in 1809: the Sultan of Muscat. The Sultan had been an ally of the Government since the signing of the 1798 Anglo-Omani treaty of friendship. The British considered the Sultan's control of the Gulf of Oman to be important for regional stability and the protection of British interests. When the Saudis occupied the Omani interior and threatened to capture Oman's coastal towns in 1809, the British feared that Saudi dominance would destabilize the region and threaten India's line of communication with Britain, so they sent a small naval force to protect these towns, particularly Muscat. However, the Sultan's subsequent requests for British protection over the next two decades were refused until 1829, when the Government adopted a policy of normally granting the Sultan the protection of the Gulf Squadron. Britain did not sign a formal defense agreement with Oman until 1958.

The next rulers to enjoy British protection were the shaikhs of Abu Dhabi, Dubai, Ajman, and the Qawasim of Sharjah, Ras al-Khaimah, and Lingah, who signed the 
first Maritime Truce with the Resident in May 1835. The Truce was an experimental ban on maritime warfare during the six-month pearling season (normally MayOctober), guaranteed by the Resident and enforced by the Gulf Squadron. The idea of the Truce was proposed during a meeting at the British naval depot in Basidu on Qishm Island between the acting Resident, Lieutenant Samuel Hennell (1834-5), Shaikh Sultan bin Saqr al-Qasimi of the Qawasim (Ruler 1803-66), and Shaikh Shakhbut Al Nahyan of Abu Dhabi (father and representative of the Ruler) - a meeting convened by Hennell to recover property seized by two Abu Dhabi pirates in recent raids on Sharjah ships. During the meeting, Hennell suggested the idea of an all-encompassing maritime truce, beyond that of the General Treaty of 1820 banning piracy. The shaikhs liked the idea, so Hennell sent one of the Gulf Squadron's ships over to Dubai to ask Shaikh Ubaid bin Said al-Maktum (co-Ruler 1833-6) to join the discussions. Shaikh Ubaid sailed immediately to Basidu, followed soon after by Shaikh Rashid al-Nuaimi of Ajman (Ruler 1816-38). The four shaikhs met with Hennell to explore the idea of a truce. Hennell found them to be enthusiastic about the idea, so he drew up a draft truce for their consideration. The following day, on 21 May, the shaikhs met with Hennell to express their satisfaction with the terms he proposed and voluntarily signed the Truce. ${ }^{31}$ Despite this account, the popular perception in the Gulf today of the Maritime Truce and of the resulting Pax Britannica is that it was imposed on the rulers against their wishes.

The terms of the 1835 Truce, and of all subsequent Maritime Truces, obligated the rulers to 1) avoid all hostilities at sea, 2) afford full redress to any infractions by their subjects, 3) not retaliate if attacked, but report the incident to the Resident, and 4) give notice to the Resident if they intend to renew hostilities at sea after the expiry of the Truce. The Truce also obligated the Resident to 5) enforce the Truce and 6) obtain reparation for any injuries inflicted by one party on another. His obligation to mediate and protect was implied. The 1835 Truce lasted just six months, until the end of the pearling season in November. ${ }^{32}$ Days after the signing of the Truce, Hennell reported how news "came in from all quarters of the joy and satisfaction diffused amongst the inhabitants of the whole line of the Arabian Coast of the Gulf on the intelligence reaching them of the establishment of the Truce." ${ }^{33}$ The terms of the Truce, which came to be known as the "Trucial system," cast Britain in the roles of protector, mediator, arbiter, and guarantor of settlements - roles that the laws of dakhala and zabana required a protector to play. The Resident played his part, the rulers played theirs, the Truce passed without incident, and all deemed it a great success.

The following year, in April 1836, the Resident offered the rulers the opportunity to renew the Truce for the coming pearling season. All readily agreed, including the newly-independent Ruler of Umm al-Qaiwain, formerly a dependent of the Qawasim. ${ }^{34}$ Thereafter, the renewal of the Truce became an annual event. British reports clearly indicate that the annual renewal was a product of the initiative and insistence of the majority of the rulers, and was not imposed upon them by the Resident.

The idea to extend the Truce's coverage beyond the summer pearling season 
into a perpetual ban on all maritime warfare was first proposed by Shaikh Sultan of Sharjah in September 1836, just sixteen months after the introduction of the first Truce. The Resident, Major James Morrison, rejected the Shaikh's proposal, however. The Government of Bombay, Morrison explained, lacked the resources to enforce a perpetual truce. Or so he believed. ${ }^{35}$ The British were also convinced that, so long as the ban on maritime warfare permitted rulers to pursue feuds outside of the pearling season, they would be content "to allow their feuds and animosities to remain in abeyance, under the idea that after a specified date it would always be in their power to indulge their deeply rooted feelings of animosity, should they feel disposed to do so. ${ }^{\prime 36}$ Were the ban to become perpetual, it could not provide for this. Samuel Hennell (Assistant Resident 1826-38, Resident 1838-41, 1843-52) believed that

[precluding the rulers] from avenging insults, or taking satisfaction for wrongs, whether real or imaginary, would so embitter the sentiments of hatred entertained [by the rulers] towards each other, that a series of aggressions and retaliations would speedily arise, which would only tend to defeat the very object for which the peace had been negotiated. ${ }^{37}$

In 1838, when Captain Hennell toured the lower Gulf to renew the Maritime Truce for a third time, Shaikh Sultan bin al-Qasimi "not only expressed his earnest desire for a renewal of the Truce, but added that it would afford him sincere pleasure if it could be changed into the establishment of a permanent peace upon the seas." ${ }^{" 38}$ Hennell rejected the Shaikh's proposal, for the reasons just mentioned. Undeterred, the Shaikh urged the Resident to agree to an annual twelve-month truce instead. As the other rulers consented to the Shaikh's proposal, Hennell drew up a new truce accordingly, which the rulers readily signed. ${ }^{39}$

So successful were the annually-renewed Truces, that the Resident agreed to guarantee a ten-year Maritime Truce in 1843. The following year, Lieutenant Kemball observed that the rulers "are now quite as much interested in its maintenance as ourselves; and of this they exhibited ample proof in their united readiness to renew it for so long a period as ten years, or even more, had such been desired or deemed expedient." ${ }^{40}$ J. B. Kelly explains that

so changed had the shaikhs' outlook become by the time of the conclusion of the Ten Years' Truce that they often acted on their own initiative to punish infractions of the truce by their subjects, even before these had been brought to the notice of the Resident. Sometimes they even went further and acted to prevent the commission of piracy. The Shaikh of 'Ajman, for example, when a Qasimi vessel from Lingah ran aground in a storm off 'Ajman in 1845, hastened to the scene with his brothers, sword in hand, and swore to cut down the first man who tried to plunder the vessel. ${ }^{41}$

After the successful completion of the ten-year Truce in 1853, with only occasional breaches, it was evident to the British that their reasons for not granting permanent 
protection were unfounded. That year, the Resident finally invited the Rulers of the Trucial States to sign a Perpetual Maritime Truce, seventeen years after the Ruler of Sharjah first proposed the idea. All the Rulers signed without hesitation. In recognition of the shaikhdoms' membership in the Maritime Truce, the British referred to them as the "Trucial States" and to their coastline as the "Trucial Coast." The British eventually admitted the Ruler of Bahrain to the Truce in 1861, Kuwait in 1899 (de facto membership), and Qatar in 1916. Oman was never admitted to the Maritime Truce, although it did enjoy informal, conditional British protection from 1829 onwards. In practice, the British almost always granted the Sultan's request for military assistance after that date.

The slow realization that earlier British fears were unwarranted is also reflected in the gradual change in attitude of British officials in India towards the maritime protection of Bahrain. The Government of Bombay hesitated to extend the Maritime Truce to the island shaikhdom because maritime protection entailed a complete defense commitment, a commitment it was reluctant to enter into. Before 1838, the Government maintained a straightforward "no protection" policy for the reasons outlined above.$^{43}$ In 1838, however, it adopted a cautious "emergency protection only" policy that was dependent upon British approval of the Ruler. In 1851, it adopted an "unofficial protection only" policy irrespective of British approval of the Ruler. ${ }^{44}$ In 1861, after the Ruler had become increasingly warlike, attacking the ports of Hasa, the British saw the need to adopt a "permanent protection" policy. That year, the Government of Bombay induced the Ruler to join the Perpetual Maritime Truce, making it Bahrain's Protecting Power. ${ }^{45}$ Finally, in 1880, the Government of India assumed responsibility for Bahrain's foreign affairs. ${ }^{46}$ After 1861, the Resident was able to maintain political leverage with the Ruler and avoid encouraging despotism by limiting British protection to the shaikhdom. He would not guarantee the Ruler's position within the shaikhdom. Time and time again, the Resident informed the Ruler that,

it was highly desirable that the Chief of Bahrein should learn to rely on his own resources for the maintenance of his position, for as long as he could count on the constant presence of foreign support he would surely remain careless and pathetic and disinclined to exert himself in strengthening his position by good administration and a conciliatory policy towards his people. ${ }^{47}$

The only way the Ruler could secure British support for his rulership in moments of crisis was if the Resident wished it to continue. The rulers of Kuwait, Qatar, the Trucial States, and Muscat were all in the same position. This motivated most of the rulers most of the time to maintain good relations with the Resident.

Britain did not commit its army to the land defense of the Gulf shaikhdoms and Oman until the twentieth century. As always, Oman was the first to receive this protection. Although it had no treaty obligation to do so, the Government of India sent troops to Muscat in 1913 to defend the town from interior tribesmen led in 
revolt against the Sultan by the Imam of Nizwa. The troops stayed until 1921, when they were replaced by the Muscat Levy Corps (raised, trained, and led by British officers on secondment to or in the private employ of the Sultan's government). This unit became the foundation of what would later become the Sultan's Armed Forces (also raised, trained, and led by British officers). During the secessionist wars in Jebal Ahkdar (1957-9) and Dhofar (1962-1976), the Sultan's Armed Forces were augmented by units from the British Army and RAF. In 1914, shortly after the Ottoman Empire's declaration of war against Britain, the Gulf Resident assured the Ruler of Kuwait that Britain would protect him against Ottoman aggression, that Britain recognized his shaikhdom as a principality under British protection. This was followed immediately by the Government of India's public declaration of Kuwait as a British "protectorate," although it was, in fact, a "British-protected state" (as will be explained below). After the conclusion of the First World War, Kuwait continued to enjoy the full protection of the British military by sea, land, and air. In 1935, the Government of India agreed to protect Qatar by land and air in return for the Ruler's grant of an oil concession to a British oil company, which was duly given. In 1951, the British Government in London committed itself to the land defense of the Trucial States by establishing the Trucial Oman Levies (a British trained and led infantry battalion of locally-recruited soldiers paid for by the British Crown). In 1956, the British Army established a garrison of two infantry companies (over 200 soldiers) in Bahrain in response to large-scale protests directed at the Ruler and the British Government. After Iraq's attempted invasion of Kuwait in 1961, this garrison was replaced with a parachute battalion group (almost 1,000 soldiers). This brought the total number of British land, sea, and air servicemen in Bahrain to around 2,000 during $1961-71 .^{48}$

\section{The Gulf and the British Empire}

After they joined the Maritime Truce, the Gulf rulers signed other treaties with the British Governments of Bombay and India, the most important of which were the Exclusive Agreements, binding them into exclusive treaty relations with, and ceding control of their external affairs to, the British Crown. ${ }^{49}$ These were signed by the Ruler of Bahrain in 1880 and 1892, the rulers of the Trucial States in 1888 and 1892, the Ruler of Kuwait in 1899, the Saudi Ruler of Najd and Hasa in 1915 (annulled in 1927), and finally the Ruler of Qatar in $1916 .^{50}$ The Sultan of Muscat signed a limited Exclusive Agreement in 1891, which prohibited him only from ceding, selling, or leasing his domains to any foreign government or person, except the British Crown. By the 1900s, he had become dependent on British support and the Government of India was managing his foreign affairs at his request, except for countries with which he already had treaty relations (mainly France and America). ${ }^{51}$

With the signing of the Exclusive Agreements, the international legal status of the Gulf shaikhdoms became that of "British-protected states" - states under the partial suzerainty of the British Crown. Although their rulers remained as heads of state, their status vis-à-vis the British Government of India placed them constitutionally within 
the British Indian Empire (1858-1947), while their status vis-à-vis the British Crown placed them informally within the British Empire. ${ }^{52}$ Oman, however, was never declared to be anything more than an independent state in "special treaty relations" with Great Britain, despite it being a British-protected state in many respects during the first half of the twentieth century. ${ }^{53}$ Had Britain not been prevented from doing so by the Anglo-French Declaration of 1862, it would have signed an exclusive agreement with Oman, making the sultanate a British-protected state in every respect.

By the late nineteenth century, the Gulf shaikhdoms and Oman came to form a part of what Frauke Heard-Bey aptly describes as "the screen of semi-independent states and principalities ... right across the British Indian Empire's Northern frontiers and Western seaboards and along its vital communication lines with Europe." ${ }^{54}$ The Exclusive Agreements legitimized Britain's exclusion of Ottoman, German, French, and Russian influence from strategic parts of Eastern Arabia, allowing Britain to establish a cordon sanitaire to protect British India. Britain's exclusion of foreign involvement in the Gulf was intended in part to prevent Britain's rivals from establishing a naval base in the Gulf, for such a base would pose a serious maritime threat to India. This policy was most famously articulated in 1903 by Britain's Foreign Secretary at the time, Lord Lansdowne: "we should regard the establishment of a naval base or of a fortified port in the Persian Gulf by any other Power as a very grave menace to British interests, and we should certainly resist it with all the means at our disposal." ${ }^{55}$ In the decades between the signing of the Exclusive Agreements in the 1880s-90s and the discovery of oil in the 1930s, Britain's policy on the Gulf shaikhdoms, as one Gulf Resident explained, was:

to maintain the independence of the Arab Shaikhdoms so long as they preserve law and order and maintain a system of administration that will satisfy or at any rate be tolerated by their subjects, to avoid any greater degree of interference in their internal affairs than is forced upon us, but at the same time to prevent any other foreign power from dominating them or obtaining any special privileges in the Gulf. ${ }^{56}$

After the discovery of oil in Iran (1908), Bahrain (1932), Kuwait (1938), Qatar (1940), Abu Dhabi (1958), and Oman (1964), and Britain's subsequent reliance on this oil, British policy became concerned with protecting Britain's oil supply in the Gulf. This concern led Britain to expand its military commitments to the land defense of Qatar and the Trucial States, as mentioned above. It also contributed to Britain's decision to stay on in the Gulf after its withdrawal from India in 1947. That year, the British transferred responsibility for the Gulf Residency from New Delhi to London. Kuwait remained a British-protected state for another fourteen years, until 1961, while Bahrain, Qatar, and the Trucial States remained so for another twentyfour, until 1971. 


\section{Advantages and Disadvantages of British Protection}

For the Gulf rulers, there were numerous advantages and disadvantages to British protection. First, by allying with a powerful protector like the British Government of India, a ruler both reinforced his position within his shaikhdom and enhanced his shaikhdom's political status within the regional political system. The British Government of India also provided important external recognition of the most powerful ruling families, or factions within them, as the legitimate rulers over their people and their domains. ${ }^{57}$ This secured the rulers in their positions, enabling them to become more autocratic, and resulted in the gradual demise of the centuries-old pattern of protection-seeking from regional powers and the rise and fall of ruling shaikhly families. Protection and recognition of local rulers and tribal chiefs was used as a political strategy by the British throughout their empire. ${ }^{58}$ The withdrawal of British protection and recognition from a shaikhdom or its dependencies made a ruler vulnerable to a family coup d'état or a tribal secession respectively.

Second, British protection and recognition of the rulers of the Trucial States and Muscat also helped to empower most of them to dominate the independent rulers and tribal leaders of the interior, whom the British had not recognized. The result was the conversion of the interior shaikhdoms and tribal territories into dependencies of the coastal capitals. In the 1950s and '60s, the British helped the coastal rulers of Abu Dhabi, Dubai, Sharjah, Ras al-Khaimah, and Muscat to achieve complete control over these dependencies, in effect to annex them, enabling British-run oil companies to explore and drill wells there.

Third, while British protection enabled these rulers to acquire new inland dependencies, it had the opposite effect on rulers with overseas dependencies, mainly Bahrain and the Qawasim, as the British forbad all use of naval force, including the protection and control of tributary domain. Although Oman was not a signatory to the Maritime Truce, Britain treated it as if it were, preventing it from attacking other members of the Truce as well as Iran.

Fourth, British protection proved to be a double-edged sword for the rulers. It came at a high price: accountability to the Gulf Resident for any action he disapproved of. Accountability was common to both British and Arabian understandings of the protégé-protector relationship, of course, but the problem for the rulers was that the Resident was able to hold them thoroughly accountable.

Fifth, the British alone had the power to stop the cyclical pattern of protectionseeking, raiding, and invasion amongst the rulers. The Gulf Resident could use this position to his advantage as an indirect method of keeping in power those rulers who co-operated with him to maintain the Pax Britannica, and keeping out of power those who did not. Occasionally the Resident employed more direct methods, intervening personally to punish or remove rulers unwilling to co-operate with him and installing shaikhs who would uphold the Pax Britannica. Bahrain and its dependencies provide the best illustration of this, for the Resident intervened there more than in any other shaikhdom: three rulers deposed, one governor exiled, five demonstrations of firepower (including the destruction of a ruler's fort), five threats of firepower, two 
public floggings of Bahrainis, and five blockades. ${ }^{59}$ Bahrain is the only shaikhdom in which the Resident intervened directly to unseat rulers. After World War II, he was careful to work with the ruling families behind the scenes to remove rulers: Sharjah in 1965, Abu Dhabi in 1966, and Oman in 1970. One must view this in context, however. Regional protectors, like the Saudi Amir of Najd and the Sultan of Muscat, regarded such interventions as a right and intervened when they thought necessary. The fact that protégés were occasionally deposed by their protectors did nothing to diminish the general demand for protection and the willingness of the rulers to accept it.

Sixth, while British protection strengthened the position of the rulers within the regional political system, in some respects it limited the extent of their authority within their shaikhdoms. British political agents posted in Kuwait, Bahrain, Qatar, the Trucial States, and Oman frequently intervened in the internal affairs of the shaikhdoms to safeguard the lives and property of British subjects (usually Indian merchants before 1947) and British-protected persons (usually local elites). ${ }^{60}$ These interferences constrained the rulers' authority, making the business of local governance sometimes difficult and frustrating. ${ }^{61}$ If the rulers found themselves at odds with British interests and refused British "advice" on the protection of those interests, they risked British intervention. A more serious dilemma occurred when the rulers found themselves trapped between the competing interests of their people and the British. The rulers needed the support of both groups. If they sided with their people, they risked British intervention. If they sided with the British, they undermined their legitimacy in the eyes of their people. This scenario is known as "the chief's dilemma" in African studies. ${ }^{62}$ Fuad Khuri calls it the problem of "duality of authority," where local and imperial jurisdictions overlap resulting in competition and conflict. ${ }^{63}$

\section{Britain's Development of the Gulf Shaikhdoms and Oman}

Over the course of the twentieth century, Britain became more and more involved in the internal affairs of the Gulf shaikhdoms and Oman, particularly in the areas of oil, aviation, and infrastructure. Before the First World War, Eastern Arabia's importance to Britain was limited to maintaining peace and stability, protecting British ships and subjects, securing the route to India, and excluding rival imperial powers (Russia, France, Germany) from establishing a presence in the region. During the inter-war period, British officials increasingly viewed Eastern Arabia as having an intrinsic importance of its own owing to the establishment of British facilities (airfields, RAF stations, a Royal Navy base), the expansion of British business, the discovery of oil, and, after the Second World War, Britain's increasing dependency on Arabian oil and investment. After the transfer of responsibility for the Gulf Residency from New Delhi to London in 1947, the British Government adopted the attitude that it was morally responsible for the internal development of the Gulf shaikhdoms and Oman, even if it was not legally responsible. Previously, New Delhi had only supported the development of Bahrain. Now London actively promoted the development of all the 
Gulf shaikhdoms and Oman.

In 1909, the Anglo-Persian Oil Company (later British Petroleum) was formed to exploit the newly-discovered oil deposits in southwest Iran. Four years later, in 1913, the British Government acquired a controlling interest in APOC to secure a reliable oil supply for the Royal Navy at the urging of Winston Churchill, then First Lord of the Admiralty. In time, APOC became Britain's single largest overseas investment and the security of Gulf oil became an important element of British foreign and defense policy. The Government of India secured undertakings from the rulers of Kuwait (1913), Bahrain (1914), Qatar (1916), the Trucial States (1922), and Oman (1923) to grant oil concessions only to companies approved by the British Government. The Government's intention was to exclude non-British applicants, or at least ensure that those concessions granted to non-Britons were placed under British governmental supervision. The oil companies that were subsequently established in Kuwait (1934), Qatar (1935), the Trucial States (1935), and Oman (1937) were all British-owned to a degree, while those established in Bahrain (1929) and Saudi Arabia (1933) were American-owned. After the subsequent discovery of oil in Bahrain (1932), Kuwait (1938), Qatar (1939), the Trucial States (1958), and Oman (1963), the British Government encouraged the Gulf rulers to invest their surplus oil revenues in Britain. Kuwait became the most active investor, establishing the Kuwait Investment Board (now the Kuwait Investment Office) in London in 1953. In time, Kuwait became Britain's single-largest investor, a title it still holds today. By 1967, it was also the single-largest foreign holder of sterling.

After the First World War, the British Government made a concerted effort to promote the use of aircraft to connect the Empire more quickly and protect the Empire more cheaply. After a decade of reconnaissance and negotiations, the Government eventually secured permission from the rulers of Kuwait, Bahrain, Qatar, Dubai, Sharjah, and Oman (including Gwadar) for it to maintain airfields in their countries for the RAF and Imperial Airways, later known as British Overseas Airways Corporation, now British Airways. In 1932, Imperial Airways commenced its passenger and postal service from Britain to India, calling at Baghdad, Basra, Bahrain, Sharjah, and Gwadar. These airfields connected the Gulf to a global air network that linked Britain with its imperial possessions in Asia. To British strategists, the Gulf airfields were almost as important as the Suez Canal and the Royal Navy bases at Aden and Bahrain. The RAF maintained aircraft in Iraq, Bahrain, Sharjah, and Oman to protect British interests in the region. ${ }^{64}$

The British also played a significant role in the establishment of modern state infrastructures. All local post offices were operated by the Indian Postal Service (1860s-1947) and later by Royal Mail (1948-60s). Mail posted from Kuwait, Bahrain, Qatar, the Trucial States, and Oman during this time used British stamps portraying the British monarch. From the 1930s onward, these were over-stamped with the name of the state. After World War I, Britons closely advised on and assisted with the formation of modern governmental departments. Virtually all of the first directors of education, public works, medical services, and so on were Britons in the private employ of the local rulers, such as Sir Charles Belgrave (Advisor to the Rulers 
of Bahrain, 1926-57). ${ }^{65}$ From the 1920s on, Britain became increasingly concerned with domestic stability and security, and raised or helped raise six local police units, three RAF levy units, and over twenty army units to help keep the peace - all led by British officers and non-commissioned officers. With the exception of the RAF Levies (1942-5) and the Trucial Oman Levies/Scouts (1951-71), these units owed their loyalty to the local ruler (who paid for them), not the British Crown.

In wartime or when war threatened, these forces were augmented by soldiers from the British and British Indian armies as well as RAF fighters and bombers, all at the expense of the British Crown: Kuwait (1944-5), Bahrain (1942-5, 1956-71), the Trucial States (1942-5, 1961-71), and Oman (1913-21, 1957-9, 1965-77). As Gulf cities expanded, many of the new buildings, airports, bridges, and facilities were designed by architects and engineers from British firms like Halcrow. The British Government convinced the rulers of Kuwait, Oman, and the Trucial States to establish development offices run by Britons to oversee this expansion. The Kuwait Development Board, established in 1950, was the first of these. During 1952-4, it was run by Major-General William Hasted, the last Engineer-in-Chief of British India. During his time in office, he oversaw the building of schools, water distillation plants, and power stations throughout the emirate, the design of a new port at Shuwaikh, and the establishment of Kuwait Airways. ${ }^{66}$ The British Council was also heavily involved in the early development of secondary education in most Gulf shaikhdoms and provided university scholarships for hundreds of Gulf students to study in Britain. Britain exercised extra-territorial jurisdiction in the Gulf shaikhdoms and Oman as well: British subjects, British-protected persons, and foreigners from outside the region were subject to British law. Their court cases were adjudicated by a British magistrate, usually the local British political agent. Cases between foreigners and locals, however, were adjudicated by a Joint Court chaired by the local political agent and a judge appointed by the local ruler. ${ }^{67}$

\section{The Post-War Era: America, Arab Nationalism, and Communism}

Before Britain's withdrawal from India in 1947, British strategists viewed the Gulf as an important communications corridor linking India with Britain: first as a shipping route, then as a section of the Indo-European telegraph line (built in 1865-9 through southern Iran), and finally as an air route with a string of airfields in Eastern Arabia (built in the 1930s). With Indian independence, the transfer of responsibility for the Gulf Residency from New Delhi to London, and the onset of the Cold War, the Gulf's strategic importance to Britain changed. British concerns and priorities now focused on three rising influences in the Gulf: America, Arab nationalism (led by Egypt), and communism (supported by the Soviet Union and the People's Republic of China). The Arab nationalists and communists wanted Britain out of the Gulf and supported local independence movements. The US Government sometimes advanced American interests in the Gulf at the expense of Britain's, but it nonetheless wanted Britain to stay in the Gulf to prevent revolutionary Arab nationalists or communists from overthrowing the Gulf rulers and establishing republican regimes hostile to American 
and Western interests.

Originally, American involvement in the Gulf was limited to the running of hospitals established by the Dutch Reformed Church of America in Basra (1891), Bahrain (1893), Muscat (1904), and Kuwait (1910). ${ }^{68}$ To this was added American oil companies: the Bahrain Petroleum Company, established in 1929 by Chevron (then known as Socal); the Kuwait Oil Company, jointly established by Gulf Oil and APOC in 1934; and Casoc in Saudi Arabia, established by Chevron in 1933 (renamed Aramco in 1944), which came to be owned by Chevron, Texaco, Esso, and Mobil. These companies received the backing of the US Government. This backing led to occasional tension and, in 1952, to direct conflict when Saudi forces occupied the Buraimi/al-Ain oasis, claimed by Saudi Arabia but ruled by Oman and Abu Dhabi. At stake were the competing oil interests of Aramco and two partially British-owned companies, Petroleum Development (Trucial States) and Petroleum Development (Oman), all three backed by their respective governments. This dispute placed a strain on Anglo-American relations in the Gulf. The British-led Trucial Oman Levies and Sultan's Armed Forces finally expelled the Saudi forces from the oasis in 1955 after an international arbitration process to resolve the dispute had broken down. ${ }^{69}$ Another source of tension was Britain's exclusion of American influence by refusing the US Government permission to establish consulates in the Gulf shaikhdoms (with the sole exception of Kuwait in 1951) and by refusing to let American companies open offices or send agents there. ${ }^{70}$ A further source of tension was the US Government's occasional attempts at conciliating revolutionary Arab nationalist sentiment, recognizing it as legitimate and distancing itself from Britain, in an effort to counter Soviet influence in the Arab world. As Arab nationalism was anti-imperialist and therefore anti-British, this policy was deplored in Whitehall, which regarded revolutionary Arab nationalism as a threat to British interests. Despite this, the British and US Governments worked closely in protecting Gulf oil and preventing the spread of communism in the region. They did not always agree on how this should be done, which caused tension between Whitehall and Washington, but relations on the ground between British and US officials were generally excellent. Washington supported Britain in its defense of Eastern Arabia, mainly because it had no desire or ability to establish an expensive military presence of its own in the Gulf beyond what it already had: an airfield in Dammam and a small unarmed naval presence headquartered at the Royal Navy base in Bahrain, both established in the 1940s, as well as occasional visits by US warships. ${ }^{71}$ In the 1960 s, with Britain fighting communist guerrillas in South Arabia and US forces fighting communist guerrillas and soldiers in Vietnam, US political support for Britain in the Gulf increased. ${ }^{72}$

The Arab League turned its attention to the Gulf shaikhdoms and Oman in the mid-1950s, increasing its efforts significantly after 1956. This was the year of Gamal Abd al-Nasir's election as President of Egypt, Britain's withdrawal of its last troops from the Suez Canal Zone, Nasir's nationalization of the Suez Canal Company, and his political victory at the end of the Suez Crisis - a sequence of events that made Nasir the undisputed leader of the Arab nationalist cause, a position he used to export his ideology of Arab Socialism, revolution, and republicanism. In the wake of Suez, 
Nasir directed his energies to forcing the British out of the rest of the Arab world and overthrowing their pro-British monarchs: in South Arabia, Jordan, Iraq, and the Gulf shaikhdoms and Oman. Nasir used the Arab League, Voice of the Arabs radio (Sawt $a l-A r a b)$, and the Egyptian Cultural Mission to achieve these aims.

The Arab League, headquartered in Cairo and with an Egyptian Secretary-General, called for Britain's withdrawal from the Gulf and appealed to Gulf Arabs to unite with the rest of the Arab world in demanding an end to European imperialism in the Middle East. Sawt al-Arab (established in 1953) broadcast to the Gulf and beyond the Arab League's pronouncements, Nasir's galvanizing speeches condemning British imperialism, and popular nationalist songs calling for the independence and unity of the Arab world. Inexpensive transistor radios had become widely available in the Gulf in the 1950s, enabling most Gulf Arabs to listen to Sawt al-Arab on a daily basis. In the 1950s and '60s, Nasir and Arab nationalism was the topic of passionate debate in every coffee house in the Arabian Peninsula. Finally, in the mid-1950s, Nasir sent the Egyptian Cultural Mission to the Gulf to promote Egyptian and pan-Arab music, films, literature, and newspapers in an effort to increase Egyptian influence amongst Gulf Arab youth. The British Government naturally viewed the Mission and Arab nationalism as a threat to its position in the Gulf, as this 1957 annual report from the Director of the British Council in the Gulf illustrates:

Last year the Egyptian Cultural Mission had no one in Qatar, this year they have six; last year they had two hundred and ninety in Kuwait, this year they have four hundred. Compare with this figure the number of Londonbased persons the Council has overseas in the whole world: two hundred and sixty. Yet it is a mistake to assume from this that we are faced only with the problem of Egyptian expansion of the type that occurred a hundred and twenty years ago [in the 1830s]. Egypt is making such headway because she stands for a pre-existing Arab Nationalism. Cairo is the cultural centre of the Arab world - its films, its newspapers and its radio influence opinion everywhere - so it is natural that Cairo should speak for the movement and that its figurehead should be Gamal Abd en-Nasser...

Britain has somehow been jockeyed into the position of appearing to oppose Arab Nationalism, of becoming the hated symbol of a weak and unsatisfactory past. We have come to stand for concepts like "colonialism" and "imperialism," concepts that have ceased to have any definable meaning but which still arouse blind and irrational hatred; you cannot argue with blind hatred. $^{73}$

The efforts of the Egyptian Cultural Mission were reinforced by hundreds of teachers from Egypt and other Arab republics, recruited from the 1930s onward by the Gulf governments. These teachers promoted Arab nationalism in their classrooms, using Egyptian textbooks written for this purpose. As a result of the combined efforts of Nasir, the Arab League, the Egyptian Cultural Mission, and Arab nationalist teachers, 
the popularity of Nasir and pan-Arabism spread rapidly throughout Eastern Arabia, dividing the loyalty of Gulf Arabs between Nasir and the Arab cause on the one hand and their own rulers (whom Nasir condemned as British lackeys) on the other. Pictures of Nasir appeared in shops and cafes throughout the Gulf shaikhdoms and Oman, often alongside portraits of the local ruler, illustrating the increasing dual loyalty of Gulf Arabs.

Although Arab nationalism was widely supported in the Gulf in the 1950s and 60 s, demonstrations and unrest were relatively rare and mild compared to the rest of the Arab world or European colonial world. ${ }^{74}$ The only full-scale riots occurred in response to Britain's invasion of Egypt in 1956 and Israel's invasion of its Arab neighbors in 1967, which Sawt al-Arab falsely accused Britain of assisting. A number of militant nationalist organizations formed, the most prominent being the Arab Nationalist Movement with branches or followers throughout Eastern Arabia: the National Front of Dubai (1953-60s), the Oman Liberation Army (1957-61), and Dhofar Liberation Front (1965-7). These organizations engaged in acts of sabotage and terrorism; the last two also fought a guerrilla campaign against the Sultan's Armed Forces. As with the unrest and riots, sabotage and terrorism were also relatively rare, the most infamous case being the Oman Liberation Army's bombing of the British India Steam Navigation Company ship Dara in 1961 off the coast of Dubai, which sunk the ship and killed 214 passengers and twenty-four crew members. ${ }^{75}$ Some of these nationalist organizations, or factions within them, embraced communist ideology in the 1960s and established links with the Soviet Union, the German Democratic Republic (East Germany), the People's Republic of China, and the People's Democratic Republic of Yemen (the former British colony and protectorates of Aden), which provided them with support.

The growing influence of Arab nationalism brought the Gulf shaikhdoms and Oman to global attention, with the result that rulers and British officials attracted mounting criticism from anti-colonialists around the world, particularly in the UN General Assembly. The most common criticisms were that Britain was isolating the Gulf from the rest of the Arab world, that foreign control of the Arab world could no longer be justified, and that Britain was protecting undemocratic "feudal despots." The rulers and British Government responded by downplaying their close relationship and taking steps to deflect this criticism. Many rulers adopted the rhetoric of Arab nationalism and socialism, and publically praised Nasir. The rulers found themselves in an increasingly awkward position in the 1950s: they knew they must embrace Arab nationalism (and its call for independence) to retain the support of their people, yet their rulerships and national defense depended on continuing British support. They needed the backing of both groups. Such was the pressure on local rulers to distance themselves from Britain that, in 1957, the Ruler of Bahrain reluctantly retired his British advisor, Sir Charles Belgrave, the de facto Prime Minister of the country. The previous year, the same pressure had forced the pro-British King of Jordan to retire General Sir John Glubb, Commander of the Arab Legion, and request Britain to withdraw its troops from his country in 1957. Mounting international criticism of Britain's position in the Gulf also constrained the influence of the Gulf Resident 
and his political agents, undermining their ability to promote unpopular reforms or development that the British Government wanted to see implemented. Faced with this problem, the British Government found it best to grant more and more autonomy to the rulers in the 1960s in an effort to deflect criticism and spare the rulers. Such was the strength of Arab nationalism in Kuwait that it contributed to the British Government's decision to grant Kuwait independence in 1961, ten years before the other Gulf shaikhdoms, although Kuwait remained under British protection until $1971 .{ }^{76}$

From the 1950s onward, the British and their US allies increasingly saw the Gulf in the context of the Cold War between the capitalist West and communist world. The Soviet Union began to actively support those in the Middle East seeking to rid their countries and the region of European imperialism. In the 1960s, the Soviets were joined in their efforts by the People's Republic of China and German Democratic Republic. $^{77}$ The British had long suspected Imperial Russia and its successor of seeking to secure a warm water port in the Gulf and had taken effective steps to prevent that from happening. In the 1950s and 60s, however, they faced a new threat: socialist and communist revolutionaries seeking to overthrow pro-British monarchies and establish Arab republics with the assistance of Moscow. They succeeded in Egypt (1952), Iraq (1958), North Yemen (1962), South Yemen (1967), and Libya (1969). This movement manifested itself in the Gulf in the form of the Popular Front for the Liberation of the Occupied Arabian Gulf (PFLOAG), a Marxist-Arab nationalist guerrilla organization formed in 1968 out of the Dhofar Liberation Front (DLF), formed four years earlier to fight for the independence of the Omani province of Dhofar. Unlike the DLF, however, the PFLOAG fought to extend communist revolution to all the Gulf states and had small branches throughout Eastern Arabia. The PFLOAG received indoctrination, training, support, and military equipment from the newly-formed People's Democratic Republic of Yemen (next door to Dhofar) as well as the People's Republic of China, the Soviet Union, the German Democratic Republic, Iraq, and militant communist Palestinian organizations. In northern Oman, the National Democratic Front for the Liberation of Oman and the Arabian Gulf (NDFLOAG) was formed in 1970 to complement the PFLOAG's activities in the south, but it was defeated the following year. In the 1971, the two organizations merged, changing their name to the Popular Front for the Liberation of Oman and the Arab Gulf, keeping the same acronym. In 1974, the PFLOAG's Omani and nonOmani branches parted ways; the Omani branch renaming itself the Popular Front for the Liberation of Oman (PFLO). The Sultan of Oman eventually defeated the PFLO by 1976 with the military support of Britain, Iran, and Jordan. ${ }^{78}$

\section{Britain's Withdrawal}

Despite increasing Arab nationalist pressure to seek independence from Britain, the Gulf rulers feared the vulnerability that independence would bring. After Britain's military withdrawal from Princely India and central Egypt in 1947 and the emirates of South Arabia in 1967, the ruling families of these countries were all overthrown 
and replaced by republican governments. In 1958, the pro-British royal family of Iraq was slaughtered in a military coup and the pro-British royal family of Jordan came close to being ousted by revolutionary Arab nationalists. The same would no doubt happen to the ruling families of the Persian Gulf if Britain withdrew its protection from them.

The first Gulf shaikhdom to receive independence from Britain was Kuwait in 1961. At first sight, this seems odd, since Kuwait was the most vulnerable of the Gulf shaikhdoms: Britain had come to its defense in 1899, 1901, and 1914 against the Ottoman Empire and in 1920 and 1928 against tribal forces from Saudi Arabia. Kuwait had formed a nominal district of the Ottoman Empire from 1871 to 1914 and, after the formation of Iraq in 1920, many Iraqis believed the shaikhdom should be annexed. Furthermore, Britain was heavily dependent on Kuwaiti oil and investment. Nevertheless, the British Government had good reasons for granting Kuwait independence. First, Arab nationalism was strong in Kuwait and Kuwaitis wanted independence, placing the Ruler under immense pressure. The Ruler of Kuwait had effectively asked for independence in 1958 when he requested the right to manage his own foreign affairs and for Kuwait to join international organizations such as the Arab League and the United Nations. Second, by 1960, Kuwait had benefited from fourteen years of vast oil revenues, enabling it to establish a modern state infrastructure and pay its own way in the world. Unlike the other Gulf states under British protection, Kuwait was ready to manage its own foreign affairs and the expense that entailed without British help. Third, Kuwait still needed British protection. As Britain did not maintain an operational military force in Kuwait, independence would not require a military withdrawal. Britain could defend Kuwait and its oilfields from its military base in Bahrain, augmented by British forces from Aden and beyond if necessary. Kuwait's independence would not undermine British hegemony in the Gulf therefore. Fourth, Kuwait promised to continue its investments in Britain, particularly the Sterling Area ${ }^{79}$ In this context, the old treaty relationship was redundant and embarrassing for both parties. A new Treaty of Friendship was accordingly signed on 19 June 1961, granting Kuwait independence. The Arab League admitted Kuwait to membership one month later, followed by the United Nations in 1963. But Kuwait's independence was not like that of Bahrain, Qatar, and the Trucial States, for Britain's defense commitments to Kuwait did not change.

Within days of Kuwait's independence, the Iraqi Prime Minister, Colonel Abd al-Karim Qasim, announced that Kuwait was historically a part of Iraq and that he intended to annex it. The Ruler of Kuwait reluctantly requested British protection. On 1 July, a 600-man British defense force landed in Kuwait; within weeks there were 7,000 British troops in the emirate. Although a necessity, the sight of British troops in Kuwait was politically unsustainable. Pressure from Arab nationalists placed the Ruler and the British Government in an awkward position. A solution was quickly found and the troops were replaced with an Arab League peacekeeping force by October ${ }^{80}$ The other Gulf rulers had watched the Kuwait crisis closely. It was clear to everyone that independence would bring vulnerability. All of the Gulf states had territorial disputes with each other. Iran claimed Bahrain and islands ruled 
by Sharjah and Ras al-Khaimah. Saudi Arabia claimed parts of Qatar, Abu Dhabi, and Oman. Qatar claimed islands belonging to Bahrain. Bahrain claimed parts of western Qatar. All the borders between the Trucial States were disputed. The region of Jebel Akhdar in central Oman had fought for independence from Muscat with Saudi backing during 1957-9 and, in 1962, Dhofari separatists in southern Oman were to launch a fifteen-year guerrilla war against the Sultan. If Britain were to withdraw its military from the Gulf, a land-grab would likely ensue and the rulers of Kuwait and Oman might be overthrown. War could break out and disrupt the West's oil supply. The British Government reassured the Gulf rulers by promising them that it had no intention of withdrawing from the Gulf and by building up its forces in the region. The lessons learned from the Kuwait crisis led to the establishment in 1962 of the Persian Gulf Joint Task Force, consisting of one parachute brigade group, two RAF fighter squadrons, and an enlarged naval squadron of three destroyer escorts and six coastal minesweepers. The British Army brigade and RAF squadrons were stationed in Bahrain and Sharjah, while the Royal Navy squadron was headquartered in Bahrain. The British Army and RAF units stationed in Oman from 1965 onward to defeat the Dhofari rebels did not form part of the Joint Task Force.

In January 1968, however, the rulers received a rude shock. That month, the Labour Government under Harold Wilson declared it could no longer afford the £12 million a year it cost to keep its forces in the Gulf and would be withdrawing its military by the end of $1971 .{ }^{81}$ The Government's explanation was that this formed a logical part of its overall "East of Suez" withdrawal plan (Aden, Singapore, and Malaysia), announced in 1966-7, which had been made for financial reasons: the dire state of the British economy and the urgent need to cut costs. Recent scholarship has shown that this was untrue. The Government could afford to keep its forces in the Gulf, especially given the importance of Gulf oil to the British economy: nearly half the oil used in Britain came from there and $£ 12$ million was a small price to pay for the protection of Gulf oil exports worth $£ 2$ billion a year. The reason for Wilson's decision to withdraw was the fear that keeping British forces in the Gulf would undermine Labour's attempts to justify to the British electorate the deep cuts it was about to make to the civil budget, particularly social programs such as the National Health Service. ${ }^{82}$ The withdrawal plan did not apply to Oman, however.

The responses to Labour's decision are interesting. The Arab world beyond the Gulf as well as the communist bloc were naturally pleased with the announcement. The Conservative opposition in Parliament, US Government, and Gulf rulers were horrified. In the House of Commons, a former Colonial Secretary, Iain Macleod, described the abandonment of the Gulf shaikhdoms as "shameful and criminal," another former Colonial Secretary, Reginald Maudling, called it a breach of trust, and the former Prime Minister, Sir Alec Douglas-Home, accused Wilson of dereliction of duty. The American President, Lyndon Johnson, was angered by the decision; most US officials regarded it as a betrayal. America was bogged down in Vietnam and could not afford the necessary military forces to fill the security vacuum Britain was about to create. US officials feared British withdrawal would give the Soviets an opportunity to establish a military presence in the region, a presence that would 
clearly threaten the West's access to Gulf oil. ${ }^{84}$ The King of Saudi Arabia was very understanding of the decision and the Shah of Iran was delighted, while the remaining Gulf rulers felt betrayed and feared for the safety of their countries. In an effort to reverse the decision, the rulers of Abu Dhabi, Dubai, and Qatar offered to pay for Britain's continued military presence ${ }^{85}$ while the Kuwaiti Government said it was willing to consider financial contributions. ${ }^{86}$ Several days after these offers were made, the Secretary of Defense, Denis Healey, made the following comment on BBC television:

Well I don't very much like the idea of being a sort of white slaver for the Arab sheikhs. I think we must decide, as far as the Gulf's concerned, what it's in our own British interests in the long run to do, consistent with our commitments. And I think it would be a very great mistake if we allowed ourselves to become mercenaries for people who would like to have a few British troops around. ${ }^{87}$

The next day, Healey sent a formal apology to the Gulf rulers expressing "regret for any offence he may unintentionally have given by the way in which he phrased certain remarks" and his appreciation for the "spirit" in which the rulers had made their offer. ${ }^{88}$ Offence aside, Healey was also ill-informed, for the practice of other governments paying for the upkeep of British troops overseas had been wellestablished for centuries. British Army regiments stationed in British India, for instance, had always been paid for by Indian taxpayers and, at the time of Healy's statement, West German taxpayers were contributing to the cost of the British Army of the Rhine and Hong Kong taxpayers were footing the bill for the British garrison protecting them. ${ }^{89}$ Most significant of all were the hundreds of British Army, RAF, and Royal Navy officers and non-commissioned officers serving on secondment to Gulf militaries at the time and ever since, all paid for by the Gulf governments.

Exactly two years later, in the run-up to the 1970 general election, the leader of the Conservative Party, Edward Heath, announced he would reverse the decision to withdraw from East of Suez if he won the election. Once in office as Prime Minister, however, Heath discovered that preparations for withdrawal and local expectations of independence had advanced too far to be reversed. ${ }^{90}$ The withdrawal would have to proceed as scheduled. Unable to reverse the decision, Heath did two things to ensure some measure of protection was in place for the Gulf shaikhdoms after Britain's withdrawal. First, he established an interdepartmental working group to study the problem of defense in the wider Indian Ocean beyond 1971. The group recommended that America be encouraged to expand its military presence in the Indian Ocean. Negotiations between Whitehall and Washington over the next few years led to the establishment in 1977 of an Anglo-American naval and air base just over the horizon from the Gulf, at Diego Garcia (an island in the Crown colony of British Indian Ocean Territory), from which to protect Gulf oil fields, police the shipping lanes along which Gulf oil travelled, and counterbalance the increasing Soviet naval presence in the Indian Ocean region. ${ }^{91}$ Second, Heath offered defense 
agreements to the rulers providing for British naval and air assistance, "loan service officers" (serving officers seconded from the British armed forces) to help with military training and leadership, and other forms of military support.

Britain's withdrawal from the Gulf shaikhdoms in the last months of 1971 was a low-key affair in all but one respect. Bahrain was the first to receive independence on 15 August and was admitted to the United Nations the following month. Fifteen months before independence, the Shah of Iran publically relinquished his claim to the island after the UN ascertained that virtually all Bahrainis rejected a union with Iran. Qatar was the next state to receive independence, on 3 September. It was admitted to the UN later that month. The last to receive independence, on 2 December, were the Trucial States, which joined together to form the United Arab Emirates and were admitted to the UN the same month. After the independence of the Gulf shaikhdoms, the British political agents posted to them were promoted to ambassador. Oman, although legally an independent country, had enjoyed British protection since the early nineteenth century and had its foreign affairs managed by Britain at the Sultan's request since the early twentieth century. After Sultan Qaboos Al bu Said seized power in July 1970, he asserted control over his foreign affairs and established embassies around the world. At that stage there were no ambassadors in Oman and only two consuls-general: one British and one Indian. In August 1971, the British Government promoted its consul-general to ambassador, the first ambassador in Oman since the eighteenth century. Oman was admitted to the UN in October 1971; other countries opened embassies in Oman soon after. On 30 November 1971, the day before Britain withdrew its military from the Gulf, Iranian forces seized three islands belonging to Ras al-Khaimah and Sharjah. The fact that these islands were still under British protection enabled the Shah to deflect anger in the Arab world towards Britain. Arab condemnation of Britain was swift. Iraq expelled its British ambassador and Libya nationalized the holdings of British Petroleum. ${ }^{92}$ Britain's failure to defend the islands cast a dark cloud over an otherwise happy occasion for all concerned. Local bitterness about Britain's betrayal was short-lived, however, and blame was soon redirected at Iran.

British forces withdrew from their bases in Bahrain and Sharjah on 1 December. The US Navy took over the Royal Navy base in Bahrain, which it used as a naval support unit. In 1995, the base became the headquarters of the US Fifth Fleet. British forces remained in Oman, however, because of the Government's continuing commitment to assist the Sultan in his fight against the Dhofari rebels and because of the continuing importance of the RAF base on Masira Island (1943-77). British forces did not withdraw from Oman until 1977, a year after the final defeat of the Dhofari rebels. It was this defeat and the failure of communist parties elsewhere in the Gulf to gain popularity, as well as America's military support of Saudi Arabia and Iran in the 1970s (its Twin Pillar policy) and the establishment of the AngloAmerican base at Diego Garcia in 1977, that prevented the Soviet Union from filling the vacuum left by Britain's departure.

The handover of British military facilities (bases, airports, hospitals) in the shaikhdoms in 1971 and Oman in 1977 was conducted smoothly. Indeed, the word 
"handover" is slightly misleading, for hundreds of Britons remained behind, as officers and civil servants seconded to, or in the private employ of, the Gulf governments, running the police, airports, hospitals, and newly-formed militaries. Many remain there today. For instance, in 1998 there were 172 British loan service officers in the Gulf ${ }^{93}$ and, in 2009, there were around 350 former British military officers and senior non-commissioned officers employed by the UAE Government alone. ${ }^{94}$ When a long-serving British advisor to the Amir of Bahrain was asked in 1999 how things had changed after Britain's withdrawal from the Gulf, he replied "British withdrawal? What withdrawal? We're still here!"95 The question of continuing British influence over Gulf Arab governments is a sensitive subject and one impossible to quantify. There is no doubt that Britons in senior positions in the Gulf do exercise influence as old and trusted friends whose loyalty is to the ruler, not the British Crown, but public knowledge of their presence is still a source of embarrassment because of its imperial associations. For this reason, these people keep a low profile and the local press usually avoids mention of them. One of the duties of British ambassadors in the Gulf is to maintain close contact with them, for they serve as a valuable back channel of communication with the local governments, facilitating the quick and informal exchange of information should the need arise.

\section{Conclusion}

This article has shown how the British Government of India came to accept the role of guardian of the Gulf and to behave, on the whole, as the rulers expected a protector to behave. This legitimised Britain's involvement in terms of Arabian political culture and meant that the Gulf Resident's authority in the shaikhdoms was not based solely on treaties. From the rulers' perspective, the Resident was a Gulf ruler himself, except that he was the most powerful and influential ruler they had ever known. The Gulf rulers gave him the respectful titles of $R a^{\prime}$ is al-Khalij (Chief of the Gulf) and Fakhamat al-Ra'is (His High Presence the Chief). ${ }^{96}$ For the most part, the Pax Britannica benefited the Gulf shaikhdoms as much as it did the British. This explains why the Pax was so successful: it was largely self-enforcing. British protection was not imposed, it was sought after and welcomed by the Gulf rulers, and naturally so, for it secured their rulerships and safeguarded their domains. In this respect, the story of the Gulf shaikhdoms and Oman is similar to that of other small states: most need outside protectors.

British protection of the Gulf shaikhdoms and Oman came to be viewed by some as unsolicited and unwanted in the $1950 \mathrm{~s}$ and ' $60 \mathrm{~s}$ when the memories of the turbulent years before the Maritime Truce had became distant, the benefits of British protection were less apparent, and Britain's exclusive presence (based on the Exclusive Agreements) was felt by some Gulf Arabs to be more beneficial to the British than to them. ${ }^{97}$ Even so, the rulers' need for British protection remained, as witnessed by their responses to Britain's withdrawal. One need only compare these responses and Britain's smooth withdrawal from the Gulf with its bloody withdrawal from Palestine in 1948, Egypt in 1956, Cyprus in 1960, and Aden in 1967 to appreciate 
the difference between Britain's involvement in the Gulf and its involvement in the rest of the Middle East. Since independence, some Arab nationalists have regarded the high levels of collaboration during the British era as an embarrassment because of its sharp contrast with the experience of other Middle Eastern countries that fought Britain or France for independence. This embarrassment has led some Gulf Arab governments to downplay the British era in their national histories. Bahrain is the most extreme example of this: one finds no mention of the British era in the Bahrain National Museum, while the King's own history of his country omits the British era altogether. ${ }^{98}$ Embarrassment about the British era, as well as political pressure within the Gulf itself, has motivated some historians to force the Gulf shaikhdoms into the same mould as Algeria and Egypt, to make the story of "oppression, opposition, and liberation" their story as well. The problem is that one can only do this by presenting exceptional incidents as if they were common occurrences and the views of a few as if they were the views of the many.

If one were to believe these unbalanced histories of the British era, one would expect the British legacy in the Gulf to be negative. Yet it is anything but. After independence, Gulf citizens and their governments did not cut their links with Britain, they strengthened them. Hundreds of British loan service officers and "contract officers" (mercenaries) still serve in the armed forces of the GCC. Britain has remained one of the largest military suppliers to the Gulf Arab states since their independence. The rulers of Oman, Dubai, Qatar, and Bahrain are all graduates of British military academies (Sandhurst and Mons), as are hundreds of Gulf military officers. Thousands of Gulf citizens are graduates of British schools and universities. Even more keep summer homes in Britain. British suppliers, such as Marks \& Spencer and Land Rover, are ubiquitous in the Gulf. British architectural and engineering firms such as Atkins have been awarded a lion's share of the construction projects awarded to foreign firms since independence. British schools can be found in every Gulf city and are attended by British and Gulf children alike. British advisors and senior civil servants still work in every Gulf government. The GCC is the second most important trading bloc for Britain after the European Union, with Kuwait Britain's largest investor and Dubai Britain's ninth largest trading partner. The British expatriate communities in the GCC states have grown considerably since independence. Around 171,500 British expats now live in the Gulf Arab states and another 1.4 million visit each year. ${ }^{99}$ Every middle class Briton, it seems, has a friend or relative who has lived in or visited the Gulf. Members of Britain's Royal Family pay official visits to the Gulf Arab states almost every year to promote Britain's commercial and cultural links with them, links which appear to be as strong, if not stronger, than its links with former colonies like Australia, New Zealand, and Canada.

Despite this legacy, the GCC states have not remained dependent on Britain by any means. To guarantee their defense, they have pursued interdependence with several powerful Western countries through the strategic awarding of military contracts, aircraft contracts, and construction contracts, as well as heavy foreign investments, to ensure that these countries have a vested interest in Gulf security beyond that of oil. The wisdom of this approach has paid off many times over, 
as witnessed by defense agreements with America, Britain, and France, among others; the establishment of CENTCOM; the international naval force protecting Gulf shipping since the 1980s; the formation of an international coalition force to liberate Kuwait in 1991; the establishment of the US Fifth Fleet in 1995 to protect the Gulf; America's maintenance of military bases in Bahrain, Qatar (since 2002), and Saudi Arabia (until 2003) and smaller camps in the remaining Gulf states; France's establishment of a naval base in the UAE in 2009; and the continuing commitment of America and some EU states to Gulf security. In this respect, there is a strong continuity from the British era to the present: a continuing dependence on outside protectors, but one now strategically balanced to support independence. 


\section{ABBREVIATIONS}

$\begin{array}{ll}\text { Asst. } & \text { Assistant } \\ \text { For. } & \text { Foreign } \\ \text { IOR } & \text { India Office Records, British Library, London } \\ \text { PRPG } & \text { Political Resident in the Persian Gulf } \\ \text { Sec. } & \text { Secretary } \\ \text { SNOPG } & \text { Senior Naval Officer in the Persian Gulf } \\ \text { TNA } & \text { The National Archives of the United Kingdom (formerly the PRO) }\end{array}$

\section{NOTES}

1 Pelly (PRPG) to Gonne (Sec., Bombay For. Dept.), 19 June 1869, L/P\&S/9/15 (IOR). Also see Peter Lienhardt, The Shaikhdoms of Eastern Arabia, ed. Ahmed al-Shahi (Basingstoke: Palgrave, 2001), p. 97.

2 I present this argument at greater length in James Onley, "The Politics of Protection in the Gulf: The Arab Rulers and the British Resident in the Nineteenth Century," New Arabian Studies, 6 (2004), pp. 30-92.

3 Henry Rosenfeld, "The Social Composition of the Military in the Process of State Formation in the Arabian Desert," Part I, The Journal of the Royal Anthropological Institute of Great Britain and Ireland, 95 (1965), pp. 78-9; Robert Landen, "The Arab Gulf in the Arab World 1800-1918," Arab Affairs, 1 (1986), p. 59.

4 Rosenfeld, "The Social Composition of the Military," p. 76.

5 Paul Harrison, The Arab at Home (New York: Thomas Y. Cromwell \& Co., 1924), p. 125. See James Onley, "The Politics of Protection in the Gulf," pp. 44-57 for a case study of Bahrain's tribute relations in the eighteenth and nineteenth centuries.

6 For examples of customary tribute payments, see Harold Dickson, The Arab of the Desert: A Glimpse into Badawin Life in Kuwait and Sa'udi Arabia (London: George Allen \& Unwin, 1949), pp. 443-4; Madawi al-Rasheed, Politics in an Arabian Oasis: The Rashidis of Saudi Arabia (London: I. B. Tauris, 1991), pp. 113-14.

7 Fuad Khuri, Tribe and State in Bahrain: The Transformation of Social and Political Authority in an Arab State (Chicago: University of Chicago Press, 1980), p. 20.

8 al-Rasheed Politics in an Arabian Oasis, pp. 111-17.

9 Sulayman Khalaf, "Tribal Politics and Leadership in the Raqqa Region of Syria," MA thesis (American University of Beirut, 1975).

10 Onley, "The Politics of Protection in the Gulf," p. 43.

11 Ibid., p. 57.

12 Paul Dresch, Tribes, Government and History in Yemen, (Oxford: Oxford University Press, 1989), p. 258; Sulayman Khalaf, "Settlement of Violence in Bedouin Society," Ethnolog, 29 (1990), pp. 232-3, 237.

13 Lienhardt, The Shaikhdoms of Eastern Arabia, p. 112.

14 Dickson, The Arab of the Desert, pp. 133-4; Khalaf, "Settlement of Violence in Bedouin Society," pp. 227-30, 232, 236-8. 
15 Dresch, Tribes, pp. 60-1.

16 Dickson, The Arab of the Desert, pp. 440-4.

17 Lienhardt, The Shaikhdoms of Eastern Arabia, pp. 5-8.

18 Harrison, The Arab at Home, p. 126.

19 The assumption that Maritime Truce and the resulting Pax Britannica were imposed from above can be found in the writings of most Gulf historians in the Gulf itself, such as Bashir al-Samarrai, "Military Buildup and Political Instability in the Gulf, 1965-1974," PhD dissertation (University of Denver, 1978); Sultan al-Qasimi, The Myth of Arab Piracy in the Gulf (London: Croom Helm, 1986); Abdullah Taryam, The Establishment of the United Arab Emirates, 1950-85 (London: Croom Helm, 1987); Khaldoun al-Naqeeb, Society and State in the Gulf and Arabian Peninsula: A Different Perspective (London: Routledge, 1990); Obaid Butti, "Imperialism, Tribal Structure, and the Development of Ruling Elites: A Socio-Economic History of the Trucial States between 1892 and 1939," PhD dissertation (Georgetown University, 1992); Aqil Kazim, The United Arab Emirates, AD 600 to the Present: A Socio-Discursive Transformation in the Arabian Gulf (Dubai: Gulf Book Centre, 2000).

20 I make this argument more fully in James Onley, "The Politics of Protection in the Gulf," pp. 30-92.

21 For more about Britain's Persian Gulf mail route to India, see Halford Hoskins, British Routes to India (London: Longmans, 1928).

22 For more details of this episode in Gulf history, see Louise Sweet, "Pirates or Polities? Arab Societies of the Persian or Arabian Gulf, 18th Century," Ethnohistory, 11/3 (1964), pp. 262-80; Charles Belgrave, The Pirate Coast (London: G. Bell \& Sons, 1966); Hubert Moyse-Bartlett, The Pirates of Trucial Oman (London: Macdonald, 1966); Patricia R[isso] Dubuisson, "Qasimi Piracy and the General Treaty of Peace (1820)," Arabian Studies, 4 (1978), pp. 47-57; al-Qasimi, The Myth of Arab Piracy in the Gulf (1986); Charles Davies, The Blood-Red Arab Flag: An Investigation into Qasimi Piracy, 1797-1820 (Exeter: University of Exeter Press, 1997); Patricia Risso, "Cross-Cultural Perceptions of Piracy: Maritime Violence in the Western Indian Ocean and Persian Gulf Region during a Long Eighteenth Century," Journal of World History, 12 (2001), pp. 293-319.

23 For a history of the Gulf Residency, see James Onley, The Arabian Frontier of the British Raj: Merchants, Rulers, and the British in the Nineteenth-Century Gulf (Oxford: Oxford University Press, 2007); Dennis Wright, The English Amongst the Persians during the Qajar Period, 1787-1921 (London: Heinemann, 1977), pp. 6293; Penelope Tuson, The Records of the British Residency and Agencies in the Persian Gulf. IOR R/15 (London: India Office Records, 1979), pp. 1-9; Glen Balfour-Paul, The End of Empire in the Middle East: Britain's Relinquishment of Power in Her Last Three Arab Dependencies (Cambridge: Cambridge University Press, 1991), pp. 96-136.

24 For more about these agents, see Onley, The Arabian Frontier of the British Raj. A chart of the agencies can be found in appendix a.

25 Rupert Hay, The Persian Gulf States (Washington, DC: The Middle East Institute, 1959), p. 20.

26 For the Gulf Squadron's strength through the years, see Lt Charles Low, History of the Indian Navy, 1613-1863, 1 (London: Richard Bentley \& Son, 1877), pp. 536-41; Jerome Saldanha (ed.), Précis of Naval Arrangements in the Persian Gulf, 1862-1905 
(Calcutta: Superintendent of Govt Printing, 1906), pp. 1-10; Anthony Preston and John Major, Send a Gunboat! A Study of the Gunboat and Its Role in British Policy, 18541904 (London: Longmans, 1967). For Britain's naval presence in the Gulf in general, see R. Parry, "The Royal Navy in the Persian Gulf," Journal of the Royal United Services Institute, 75 (May 1930), pp. 314-31; K. Sridharan, A Maritime History of India, 2nd edn. (New Delhi: Ministry of Information and Broadcasting, 1982); Edward Ingram, "A Scare of Seaborne Invasion: The Royal Navy at the Strait of Hormuz, 1807-1808," Military Affairs, 46/2 (1982), pp. 64-8; Anita Burdett (ed.), Persian Gulf and Red Sea Naval Reports 1820-1960, 15 vols. (Slough: Archive Editions, 1993); Penelope Tuson, "Some British Views of Bahrain: The Work of the Bombay Marine and Indian Navy, 1785-1863," in Abdulla bin Khalid Al Khalifa and Michael Rice (eds.), Bahrain through the Ages: The History (London: Kegan Paul International, 1993), pp. 525-47; Donald Hastings, The Royal Indian Navy, 1612-1950 (London: McFarland \& Co., 1988).

27 Hennell to Govt of India, 26 May 1835, F/4/1596, collection 64625 (IOR), reprinted in Arnold Kemball, "Observations on the Past Policy of the British Government towards the Arab Tribes of the Persian Gulf” (1844), in R. Hughes Thomas (ed.), Selections from the Records of the Bombay Government, new ser., 24 (Bombay: Bombay Education Society Press, 1856), p. 68 (n. *). Reprinted as Arabian Gulf Intelligence (Cambridge: Oleander Press, 1985).

28 Details of these requests can be found in Thomas (ed.), Selections, pp. 61-74, 12165, 187-234, 313-520 and John Lorimer, Gazetteer of the Persian Gulf, 'Oman, and Central Arabia, Vol. 1: Historical (Calcutta: Superintendent of Govt Printing, 1915), pp. 842-946.

29 Morrison (PRPG) to Sultan al-Qasimi, Sept. 1836, qtd. in Kemball, "Observations on the Past Policy" (1844), in Thomas (ed.), Selections, p. 69.

30 Kemball, "Observations on the Past Policy" (1844), in Thomas (ed.), Selections, pp. $62-3,68,73$. Kemball was, in fact, merely repeating the findings of reports written by his predecessors. The comments that the Gulf rulers "deem the guarantee of the British to any sort of arrangement a sine qua non," for instance, are actually the words of Lt. Samuel Hennell (acting Resident 1834-5): Hennell to Govt of India, 26 May 1835, F/4/1596, collection 64625 (IOR).

31 Hennell to Govt of India, 26 May 1835, F/4/1596, collection 64625 (IOR). Parts of this report are reprinted in Kemball, "Observations on the Past Policy" (1844), in Thomas (ed.), Selections, p. 68.

32 "Translation of the terms of a truce for six months," enclosed in Hennell to Govt of India, 26 May 1835, F/4/1596, collection 64625 (IOR). The 1835 Truce does not appear in any Govt of India publications, but a copy of the 1843 Truce, which is identical except for the duration of the truce, is reprinted Kemball, "Observations on the Past Policy" (1844), in Thomas (ed.), Selections, pp. 86-7 and C.U. Aitchison, A Collection of Treaties..., 11: The ... Arab Principalities in the Persian Gulf, (Delhi: Manager of Publications, 1933; reprinted by Archive Editions, 1987), pp. 250-1. Hennell to Govt of India, 26 May 1835, F/4/1596, collection 64625 (IOR).

34 Kemball, "Observations on the Past Policy" (1844), in Thomas (ed.), Selections, p. 69.

35 Ibid., reprinted in Jerome Saldanha (ed.), Précis of the Affairs of the Persian Coast and Islands, 1854-1905 (Calcutta: Superintendent of Govt Printing, 1906), p. 197.

36 Hennell (Asst. PRPG) to Secretary, Bombay Political Department, 19 April 1838, qtd. 
in Kemball, "Observations on the Past Policy" (1844), in Thomas (ed.), Selections, p. 70 (n. *). This report is incorrectly dated 19 April 1830.

\section{J. B. Kelly, Britain and the Persian Gulf, 1795-1880 (Oxford: Oxford University} Press, 1968), p. 369.

42 Sharjah and Ras al-Khaimah became separate states in 1869, although the British Govt did not recognise this until 1921. Fujairah followed suit in 1901 and 1952 respectively. For details of this policy and the motives behind it, see Kemball, "Observations on the Past Policy" (1844), in Thomas (ed.), Selections, p. 69 (n. *).

44 Arnold Kemball, "Historical Sketch of the Uttoobee Tribe of Arabs (Bahrein), 18321844" (1844), Thomas (ed.), Selections, pp. 288-89; Herbert Disbrowe, "Historical Sketch of the Uttoobee Tribe of Arabs (Bahrein), 1844-1853" (1853), ibid., pp. 417, 420.

45 Jerome Saldanha (ed), Précis of Bahrein Affairs, 1854-1904 (Calcutta: Superintendent of Govt Printing, 1904), pp. 10-11.

46 Ibid., pp. 67-8.

47 Saldanha's paraphrase of a report by Ross (PRPG), July 1874, in Saldanha, Précis of Bahrein Affairs, p. 41.

48 This does not include the officers and crew of Britain's naval squadron patrolling the Persian Gulf. "Status of British Forces in Bahrain," 1 Jan., 15 Feb., and 30 Sept. 1961; secret note from PRPG to Ruler of Bahrain, 23 Oct. 1961; "Service Personnel in Bahrain,” 1 Jan., 1 Apr., 1 July, 1 Oct. 1962, FO 371/156726 (TNA, London). Also see Helene von Bismarck, "The Kuwait Crisis of 1961 and its Consequences for Great Britain's Persian Gulf Policy,” British Scholar, 2/1 (2009), pp. 75-96.

49 For analysis of the treaties, see J.B. Kelly, "The Legal and Historical Basis of the British Position in the Persian Gulf," St. Antony's Papers, 4: Middle Eastern Affairs, 1 (London: Chatto \& Windus, 1958), pp. 119-40; David Roberts, “The Consequences of the Exclusive Treaties: A British View," The Arab Gulf and the West, edited by B.R. Pridham (London: Croom Helm, 1985), pp. 1-14; Husain al-Baharna, "The Consequences of Britain's Exclusive Treaties: A Gulf View," The Arab Gulf and the West, pp. 15-37; al-Baharna, The Legal Status of the Arabian Gulf States: A Study of Their Treaty Relations and Their International Problems (Manchester: Manchester University Press, 1968).

50 For the details of the treaties, see Aitchison, A Collection of Treaties, 11: Persian Gulf.

51 My thanks to J.E. Peterson for his helpful comments on Oman's status.

52 For details, see Onley, The Arabian Frontier of the British Raj, pp. 20-9; Onley, "The Raj Reconsidered: British India's Informal Empire and Spheres of Influence in Asia and Africa," Asian Affairs, 40/1 (2009), pp. 44-62.

53 My thanks to J.E. Peterson for his helpful comments on Oman's status. For a contemporary discussion of Britain's de jure and de facto position in the Gulf, see Jerome Saldanha (ed.), Précis of ... International Rivalry and British Policy in the Persian Gulf, 1872-1905 (Calcutta: Superintendent of Govt Printing, 1906), pp. 34-5. 54 Frauke Heard-Bey, From Trucial States to United Arab Emirates, $2^{\text {nd }}$ edn. (London: 
Longman, 1996), p. 294.

55 Lord Lansdowne, Persian Gulf declaration, 5 May 1903; The Times, 6 May 1903, p. 8.

56 Biscoe (PRPG) to Wylie (Deputy For. Sec., India), 24 Nov. 1931, L/P\&S/12/3727 (IOR, London), qtd. in J.E. Peterson, Defending Arabia (London: Croom Helm, 1986), p. 37 (n. 85).

57 Onley, "The Politics of Protection in the Gulf," p. 66; J. E. Peterson "Tribes and Politics in Eastern Arabia," Middle East Journal, 31 (1977), p. 302.

58 See Colin Newbury, Patrons, Clients and Empire: Chieftaincy and Over-rule in Asia, Africa and the Pacific (Oxford: Oxford University Press, 2003).

59 This list is limited to interventions involving the ruling family. The imprisonment of opposition leaders in 1956 was in support of the Ruler. Onley, The Arabian Frontier of the British Raj, p. 131.

60 For details, see Rupert Hay, The Persian Gulf States (Washington DC: Middle East Institute, 1959); Bernard Burrows, Footnotes in the Sand: The Gulf in Transition, 1953-1958, (Salisbury: Michael Russell, 1990); Balfour-Paul, The End of Empire in the Middle East; Fatma al-Sayegh, "Merchants' Role in a Changing Society: The Case of Dubai, 1900-90," Middle Eastern Studies, 34/1 (1998), pp. 87-102; Onley, "Britain's Native Agents in Arabia and Persia in the Nineteenth Century"; Onley, The Arabian Frontier of the British Raj.

61 For details, see Ameen al-Rihani, Muluk al-Arab [Kings of Arabia] (Beirut: Dar alRihani lil-Tibaah wa al-Nashr, 1924), pp. 769-70; al-Rihani, Around the Coasts of Arabia (London: Constable, 1930), p. 303; Husain al-Baharna, British Extra-territorial Jurisdiction in the Gulf, 1913-1971 (Slough: Archive Editions, 1998).

62 See Newbury, Patrons, Clients and Empire for an excellent study of chieftaincy and imperialism.

63 Khuri, Tribe and State in Bahrain, pp. 85-108. For examples, see Rosemarie Said Zahlan, The Origins of the United Arab Emirates: A Political and Social History (London: Macmillan, 1978); Zahlan, The Creation of Qatar (London: Croom Helm, 1979); Talal Farah, Protection and Politics in Bahrain, 1869-1915 (Lebanon: American University of Beirut, 1985); Andrew Loewenstein, "“The Veiled Protectorate of Kowait': Liberalized Imperialism and British Efforts to Influence Kuwaiti Domestic Policy during the Reign of Sheikh Ahmad al-Jaber, 1938-50," Middle Eastern Studies, 36/2 (2000), pp. 101-23; Simon Smith, Kuwait, 1950-1965: Britain, the al-Sabah, and Oil (Oxford: Oxford University Press, 2000); Simon Smith, Britain's Revival and Fall in the Gulf: Kuwait, Bahrain, Qatar, and the Trucial States, 1950-71 (London: RoutledgeCurzon, 2004).

64 For more about the RAF in the Gulf and Britain's air route through the Gulf, see G. W. Bentley, "The Development of the Air Route in the Persian Gulf," Journal of the Royal Central Asian Society, 20/2 (1933), pp. 173-89; H. Burchall, "The Air Routes to India," Journal of the Royal Central Asian Society, 14 (1927), pp. 3-18; Burchall, "The Political Aspects of Commercial Air Routes," Journal of the Royal Central Asian Society, 20 (1933), pp. 70-90; Claude Keith, Flying Years (London: J. Hamilton Ltd, 1937); Philip Sassoon, "Air Routes in the Middle East," Journal of the Royal Central Asian Society, 20 (1933), pp. 394-405; Robin Higham, Britain's Imperial Air Routes, 1918 to 1939 (London: G. T. Foulis, 1960); David Lee, Flight from the Middle East: A History of the Royal Air Force in the Arabian Peninsula and Adjacent Territories, 1945-1972 (London: HMSO, 1980); J.E. Peterson, Defending Arabia, chap. 2; Fatma 
al-Sayegh, "Imperial Air Communications and British Policy Changes in the Trucial States, 1929-1952," Ph.D. thesis (University of Essex, 1990); Anita L. P. Burdett (eds.), The GCC States: National Development Records: Civil Aviation, 1920-1962, 8 vols. (Slough: Archive Editions, 1988, 2003).

65 For more about Belgrave, see Charles Belgrave, Personal Column (London: Hutchinson, 1960); Robert, Belgrave, "C. Dalrymple Belgrave: The Early Years as Advisor in Bahrain," in Abdulla bin Khalid Al Khalifa and Michael Rice (eds.), Bahrain through the Ages: The History (London: Kegan Paul International, 1993), pp. 104-22; and Belgrave's personal diaries in the University of Exeter Library, Special Collections.

66 For details, see H.M. Govt., Foreign Office, "Historical Summary of Events in the Persian Gulf Shaikhdoms and the Sultanate of Muscat and Oman, 1928-1953," PG 53 (London: Foreign Office, June 1953; reprinted by Archive Editions, 1987), pp. 60-8.

67 For more about British extra-territorial jurisdiction in the Gulf, see Salim al-Arrayed, Islamic Law as Administered in British India and in Joint British Courts in the Arabian Gulf, 1857-1947 (Manamah, Bahrain: al-Ayam Press, 2001); Husain al-Baharna, British Extra-Territorial Jurisdiction in the Gulf, 1913-1971; Nathan Brown, The Rule of Law in the Arab World: Courts in Egypt and the Gulf (Cambridge: Cambridge University Press, 1997); Onley, The Arabian Frontier of the British Raj, pp. 119-27.

68 See Lewis Scudder III, The Arabian Mission's Story: In Search of Abraham's Other Son (Grand Rapids, MI: Wm. B. Eerdmans Publishing Company, 1998).

69 For details, see Peter Clayton, Two Alpha Lima: The First Ten Years of the Trucial Oman Levies and Trucial Oman Scouts, 1950 to 1960 (London: Janus, 1994), pp. 25-7, 71-8. 171-9; Robin Bidwell (ed.), The Buraimi Memorials 1955, 5 vols. (Gerrards Cross: Archive Editions, 1987); Jane Priestland (ed.), The Buraimi Dispute: Contemporary Documents, 1950-1961, 10 vols. (Slough: Archive Editions, 1998).

70 For details, see H.M. Govt., "Historical Summary of Events in the Persian Gulf Shaikhdoms," pp. 43-5, 48, 104-05, 164.

71 See Michael Palmer, Guardians of the Gulf: A History of America's Expanding Role in the Persian Gulf, 1883-1992 (New York: Free Press, 1992); David Winkler, Amirs, Admirals, and Desert Sailors: Bahrain, the US Navy, and the Arabian Gulf (Annapolis: Naval Institute Press, 2007).

72 For more about America in the Gulf, see W. Taylor Fain, "John F. Kennedy and Harold Macmillan: Managing the 'Special Relationship' in the Persian Gulf Region, 196163," Middle Eastern Studies, 38/4 (2002), pp. 95-122; W. Taylor Fain, American Ascendance and British Retreat in the Persian Gulf Region (Basingstoke: Palgrave, 2008); Tore T. Peterson, The Decline of the Anglo-American Middle East, 1961-1969: A Willing Retreat (Sussex: Academic Press, 2006); Robert Vitalis, America's Kingdom: Mythmaking on the Saudi Oil Frontier (Stanford: Stanford University Press, 2007).

73 British Council's Persian Gulf Representative, Annual Report for 1956-7, 29 Apr 1957, BW 114/6, pp. 1-2 (TNA, London).

74 See, for example, Christopher Davidson, "Arab Nationalism and British opposition in Dubai, 1920-66,” Middle Eastern Studies, 43/6 (Nov. 2007), pp. 885-90.

75 For details of the Oman Liberation Army and Dhofar Liberation Front's terrorist activities, see J.E. Peterson, "Britain and the Oman War: An Arabian Entanglement," Asian Affairs, 63/3 (Oct. 1976), pp. 292-3.

76 For more about Arab nationalism in the Gulf, see Riad el-Rayyes, "Arab Nationalism 
in the Gulf' in B.R. Pridham (ed.), The Arab Gulf and the Arab World (London: Croom Helm, 1988), pp. 67-94.

77 For details see Fred Halliday, Arabia without Sultans (Harmondsworth: Penguin, 1974); Aryeh Yodfat, In the Direction of the Persian Gulf: The Soviet Union and the Persian Gulf (London: Cass, 1977); Aryeh Yodfat, The Soviet Union and the Arabian Peninsula: Soviet Policy towards the Persian Gulf and Arabia (London: Croom Helm, 1983); Mohamed Bin Huwaidin, China's Relations with Arabia and the Gulf, 19491999 (London: RoutledgeCurzon, 2002).

78 For details, see Halliday, Arabian without Sultans; J.E. Peterson, Oman's Insurgencies: The Sultanate's Struggle for Supremacy (London: Saqi, 2007).

79 For details, see Smith, Kuwait, 1950-1965; Simon Smith, "The Making of a NeoColony? Anglo-Kuwaiti Relations in the Era of Decolonization," Middle Eastern Studies, 37/1 (2001), pp. 159-72; Smith, Britain's Revival and Fall in the Gulf.

80 Nigel John Ashton, "Britain and the Kuwaiti Crisis, 1961," Diplomacy and Statecraft, 9/1(1998), pp. 163-81; Smith, Kuwait, 1950-1965, pp. 116-24; Rosemarie Said Zahlan, "Shades of the Past: The Iraq-Kuwait Dispute, 1961," Journal of Social Affairs, 22/87 (2005), pp. 47-80.

81 For more about Britain's withdrawal from the Gulf, see Lamia Y. Saffoury, "Britain's Withdrawal from the Persian Gulf: Decision and Background," MA thesis (American University of Beirut, 1970), pp. 104-5; D.C. Watt, "The Decision to Withdraw from the Gulf," Political Quarterly, 39/3 (1968); D.C. Watt, "Britain and the Indian Ocean," Political Quarterly, 42/3 (1971). Wm. Roger Louis, "The British Withdrawal from the Gulf, 1967-71," Journal of Imperial and Commonwealth History, 31/1 (2003), pp. 83-108; Shohei Sato, "Britain's Decision to Withdraw from the Persian Gulf, 196468: A Pattern and a Puzzle," Journal of Imperial and Commonwealth History, 37/1 (2009), pp. 99-117; Smith, Britain's Revival and Fall in the Gulf.

82 This belief was first promoted by Roy Jenkins, Chancellor of the Exchequer. Sato, "Britain's Decision to Withdraw from the Persian Gulf, 1964-68," pp. 107-12.

83 Iain Macleod qtd. in Parliamentary Debates (Hansard) (London: House of Commons), 17 Jan. 1968, col. 1819.

84 See Fain, American Ascendance and British Retreat in the Persian Gulf Region; Peterson, The Decline of the Anglo-American Middle East, 1961-1969.

85 Abu Dhabi to Foreign Office, 10 Jan. 1968, PREM 13/2209 (TNA, London), cited in Sato, "Britain's Decision to Withdraw from the Persian Gulf, 1964-68," p. 108 (n. 54); The Times (22 Jan. 1968), p. 1; The Times (26 Jan. 1968), p. 5.

86 Tapsell to Wilson, 11 Jan. 1968; Palliser to Morphet, 11 Jan. 1968; Maitland to Palliser, 11 Jan. 1968, PREM 13/2209 (TNA, London), cited in Sato, "Britain's Decision to Withdraw from the Persian Gulf, 1964-68," p. 108 (n. 56).

87 Extract from BBC TV Panorama, 22 Jan. 1968, PREM 13/2218 (TNA, London), cited in Sato, "Britain's Decision to Withdraw from the Persian Gulf, 1964-68," p. 111 (n. 70).

88 Foreign Office to Bahrain, 23 Jan. 1968, PREM 13/2218 (TNA, London), cited in Sato, "Britain's Decision to Withdraw from the Persian Gulf, 1964-68," p. 111 (n. 71).

89 See J.B. Kelly, Arabia, the Gulf and the West (London: George Weidenfeld \& Nicolson, 1980), p. 51.

90 Edward Heath, The Course of My Life (London: Hodder \& Stoughton, 1998), p. 482.

91 Peter Sand, United States and Britain in Diego Garcia: The Future of a Controversial 
Base (Basingstoke: Palgrave, 2009); John Brobst, "A Lake Up for Auction? Britain, the Indian Ocean, and Global Power, 1971-1976," paper presented at the Global Gulf conference, University of Exeter, July 2006.

92 Louis, "The British Withdrawal from the Gulf, 1967-71," p. 102.

93 This breaks down to 102 loan service officer in Oman, 58 in Kuwait, 11 in the UAE, and 1 in Bahrain. House of Commons debate, 18 March 1998, Hansard, 308, c629W (Loan Service Officers).

94 Col. David Adams (British Defense Attaché, UAE), qtd. in Daniel Bardsley, "A Man of Discipline and Honour" [obituary of Col. Edward "Tug" Wilson, first CO of the Abu Dhabi Defense Force], The National (UAE), 11 Jan. 2009.

95 Interview with Maj.-Gen. Gerald Green (Head of Bahrain Riot Police, 1956-61; Secretary to the Amir of Bahrain, 1961-2007), Bahrain, Mar. 1999.

96 Donald Hawley, Desert Wind and Tropic Storm: An Autobiography (Wilby: Michael Russell, 2000), p. 44.

97 My thanks to Frauke Heard-Bey of the Abu Dhabi Authority for Culture and Heritage for this insight.

98 Hamid bin Isa Al Khalifa, First Light: Modern Bahrain and Its Heritage (London: Kegan Paul International, 1994).

99 FCO website, www.fco.gov.uk, accessed Feb. 2007. 


\section{REFERENCES}

\section{Primary}

Aitchison, Sir Charles Umpherson, A Collection of Treaties, Engagements and Sanads Relating to India and Neighbouring Countries, 11: The Treaties, Etc., Relating to Aden and the South Western Coast of Arabia, the Arab Principalities in the Persian Gulf, Muscat (Oman), Baluchistan and the North-West Frontier Province, issued by the Foreign and Political Department, Government of India (Delhi: Manager of Publications, 1933; reprinted by Archive Editions, 1987).

Bardsley, Daniel, "A Man of Discipline and Honour" [obituary of Col. Edward "Tug" Wilson, first CO of the Abu Dhabi Defence Force], The National (UAE), 11 Jan. 2009.

Belgrave, Sir Charles, Personal Column (London: Hutchinson, 1960). Belgrave was Advisor to the Rulers of Bahrain during 1926-57.

, Personal diaries, University of Exeter Library, Special Collections.

Bentley, Squadron-Leader G. W., "The Development of the Air Route in the Persian Gulf," Journal of the Royal Central Asian Society, 20/2 (1933), pp. 173-89.

Bidwell, Robin (ed.), The Buraimi Memorials 1955, 5 vols. (Gerrards Cross: Archive Editions, 1987).

Burchall, Colonel H., "The Air Routes to India," Journal of the Royal Central Asian Society, 14 (1927), pp. 3-18.

— , "The Political Aspects of Commercial Air Routes," Journal of the Royal Central Asian Society, 20 (1933), pp. 70-90.

Burdett, Anita (ed.), The GCC States: National Development Records: Civil Aviation, 1920-1962, 8 vols. (Slough: Archive Editions, 1988, 2003).

Editions, 1993).

Burrows, Sir Bernard, Footnotes in the Sand: The Gulf in Transition, 1953-1958, (Salisbury: Michael Russell, 1990). Burrows was PRPG during 1953-8.

Clayton, Peter, Two Alpha Lima: The First Ten Years of the Trucial Oman Levies and Trucial Oman Scouts, 1950 to 1960 (London: Janus, 1994).

Dickson, Harold R.P., The Arab of the Desert: A Glimpse into Badawin Life in Kuwait and Sa'udi Arabia (London: George Allen \& Unwin, 1949).

Disbrowe, Lieutenant Herbert, "Historical Sketch of the Uttoobee Tribe of Arabs 
(Bahrein) ... from the Year 1844 to 1853" (1854), in R. Hughes Thomas (ed.), Selections from the Records of the Bombay Government, new ser., 24 (Bombay: Bombay Education Society Press, 1856), pp. 407-25. Reprinted in Arabian Gulf Intelligence (Cambridge: Oleander Press, 1985), pp. 407-25.

Green, Maj-Gen Gerald, interview, Bahrain, Mar. 1999. Green was Head of Bahrain Riot Police during 1956-61 and Secretary to the Amir of Bahrain during 1961-2007.

Hansard, 18 March 1998, 308, c629W (House of Commons debate: Loan Service Officers).

Harrison, Paul W., The Arab at Home (New York: Thomas Y. Cromwell \& Co., 1924).

Hawley, Sir Donald Desert Wind and Tropic Storm: An Autobiography (Wilby: Michael Russell, 2000). Hawley was Political Agent Trucial States during 1958-61 and British Ambassador to Oman during 1971-5.

Hay, William Rupert, The Persian Gulf States (Washington, DC: The Middle East Institute, 1959). Hay was PRPG during 1941, 1946-53.

Heath, Edward, The Course of My Life (London: Hodder \& Stoughton, 1998).

H.M. Government, Foreign Office, "Historical Summary of Events in the Persian Gulf Shaikhdoms and the Sultanate of Muscat and Oman, 1928-1953," PG 53 (London: Foreign Office, June 1953; reprinted by Archive Editions, 1987).

—, website, www.fco.gov.uk (2009). Accessed 1 February, 2007.

India Office Records (IOR), London: F/4/1596, L/P\&S/9/15.

Keith, C. H. (Claude Hilton), Flying Years (London: J. Hamilton Ltd., 1937). Keith served with the RAF in the Gulf region during 1926-30.

Kemball, Lt. Arnold, "Observations on the Past Policy of the British Government towards the Arab Tribes of the Persian Gulf" (1844), in R. Hughes Thomas (ed.), Selections from the Records of the Bombay Government, new ser., 24 (Bombay: Bombay Education Society Press, 1856), pp. 61-74. Reprinted in Arabian Gulf Intelligence (Cambridge: Oleander Press, 1985), pp. 61-74.

- "Historical Sketch of the Uttoobee Tribe of Arabs (Bahrein) ... from the Year 1832 to 1844" (1844), in R. Hughes Thomas (ed.), Selections from the Records of the Bombay Government, new ser., 24 (Bombay: Bombay Education Society Press, 1856), pp. 382-407. Reprinted in Arabian Gulf Intelligence (Cambridge: Oleander Press, 1985).

Lienhardt, Peter, The Shaikhdoms of Eastern Arabia, ed. Ahmed al-Shahi (Basingstoke: Palgrave, 2001).

Lorimer, John, Gazetteer of the Persian Gulf, 'Oman, and Central Arabia, 1: Historical 
(Calcutta: Superintendent of Government Printing, 1915).

The National Archives (TNA), London: BW/114/6, FO 371/156726, PREM 13/2209, PREM 13/2218.

Parliamentary Debates (Hansard)(London: House of Commons), 17 Jan. 1968, col. 1819.

Parry, R., "The Royal Navy in the Persian Gulf," Journal of the Royal United Services Institute, 75 (May 1930), pp. 314-31.

Priestland, Jane (ed.), The Buraimi Dispute: Contemporary Documents, 1950-1961, 10 vols. (Slough: Archive Editions, 1998).

al-Rihani, Ameen, Muluk al-Arab [Kings of Arabia] (Beirut: Dar al-Rihani lil-Tibaah wa al-Nashr, 1924).

Around the Coasts of Arabia (London: Constable, 1930).

Saldanha, Jerome (ed.), Précis of Bahrein Affairs, 1854-1904 (Calcutta: Superintendent of Government Printing, 1904; reprinted by Archive Editions, 1986).

(ed.), Précis of the Affairs of the Persian Coast and Islands, 1854-1905 (Calcutta: Superintendent of Government Printing, 1906; reprinted by Archive Editions, 1986).

(ed.), Précis of Naval Arrangements in the Persian Gulf, 1862-1905 (Calcutta: Superintendent of Government Printing, 1906; reprinted by Archive Editions, 1986).

- Précis of Correspondence on International Rivalry and British Policy in the Persian Gulf, 1872-1905 (Calcutta: Superintendent of Government Printing, 1906; reprinted by Archive Editions, 1986).

Sassoon, Sir Philip, "Air Routes in the Middle East," Journal of the Royal Central Asian Society, 20 (1933), pp. 394-405.

Thomas, R. Hughes (ed.), Selections from the Records of the Bombay Government, new ser., 24 (Bombay: Bombay Education Society Press, 1856). Reprinted as Arabian Gulf Intelligence (Cambridge: Oleander Press, 1985).

Times newspaper: 6 May 1903 (p. 8), 22 Jan. 1968 (p. 1), 26 Jan. 1968 (p. 5). 


\section{Secondary}

al-Arrayed, Salim, Islamic Law as Administered in British India and in Joint British Courts in the Arabian Gulf, 1857-1947 (Manamah, Bahrain: al-Ayam Press, 2001).

Ashton, Nigel John, "Britain and the Kuwaiti Crisis, 1961," Diplomacy and Statecraft, 9/1(1998), pp. 163-81.

al-Baharna, Husain, The Legal Status of the Arabian Gulf States: A Study of Their Treaty Relations and Their International Problems (Manchester: Manchester University Press, 1968; $2^{\text {nd }}$ edn., Librairie du Liban, 1975).

— , "The Consequences of Britain's Exclusive Treaties: A Gulf View," in Brian Pridham (ed.), The Arab Gulf and the West (London: Croom Helm, 1985).

- British Extra-Territorial Jurisdiction in the Gulf, 1913-1971 (Slough: Archive Editions, 1998).

Balfour-Paul, Glen, The End of Empire in the Middle East: Britain's Relinquishment of Power in Her Last Three Arab Dependencies (Cambridge: Cambridge University Press, 1991).

Belgrave, Charles, The Pirate Coast (London: G. Bell \& Sons, 1966).

Belgrave, Robert, "C. Dalrymple Belgrave: The Early Years as Advisor in Bahrain," in Abdulla bin Khalid Al Khalifa and Michael Rice (eds.), Bahrain through the Ages: The History (London: Kegan Paul International, 1993), pp. 104-22.

Brobst, John, "A Lake Up for Auction? Britain, the Indian Ocean, and Global Power, 1971-1976," paper presented at the Global Gulf conference, University of Exeter, July 2006.

Brown, Nathan, The Rule of Law in the Arab World: Courts in Egypt and the Gulf (Cambridge: Cambridge University Press, 1997).

Butti, Obaid, "Imperialism, Tribal Structure, and the Development of Ruling Elites: A Socio-Economic History of the Trucial States between 1892 and 1939," PhD dissertation (Georgetown University, 1992).

Davidson, Christopher, "Arab Nationalism and British Opposition in Dubai, 1920-66," Middle Eastern Studies, 43/6 (2007), pp. 879-92.

Davies, Charles Edward, The Blood-Red Arab Flag: An Investigation into Qasimi Piracy, 1797-1820 (Exeter: University of Exeter Press, 1997).

Dresch, Paul, Tribes, Government and History in Yemen (Oxford: Oxford University Press, 1989). 
Fain, W. Taylor, "John F. Kennedy and Harold Macmillan: Managing the 'Special Relationship' in the Persian Gulf Region, 1961-63," Middle Eastern Studies, 38/4 (2002), pp. 95-122.

- American Ascendance and British Retreat in the Persian Gulf Region (Basingstoke: Palgrave, 2008).

Farah, Talal, Protection and Politics in Bahrain, 1869-1915 (Lebanon: American University of Beirut, 1985).

Halliday, Fred, Arabia without Sultans (Harmondsworth: Penguin, 1974).

Hastings, Donald, The Royal Indian Navy, 1612-1950 (London: McFarland \& Co., 1988).

Heard-Bey, Frauke, From Trucial States to United Arab Emirates (London: Longman, 1982; $2^{\text {nd }}$ edn., 1996; $3^{\text {rd }}$ edn., Motivate Publishing, 2004).

Higham, Robin, Britain's Imperial Air Routes, 1918 to 1939 (London: G. T. Foulis, 1960).

Hoskins, Halford Lancaster, British Routes to India (New York: Longmans, Green, \& Co., 1928; reprinted by Frank Cass, 1966).

Huwaidin, Mohamed Bin, China's Relations with Arabia and the Gulf, 19491999 (London: RoutledgeCurzon, 2002).

Ingram, Edward, "A Scare of Seaborne Invasion: The Royal Navy at the Strait of Hormuz, 1807-1808," Military Affairs, 46/2 (1982), pp. 64-8.

Kazim, Aqil, The United Arab Emirates, AD 600 to the Present: A Socio-Discursive Transformation in the Arabian Gulf (Dubai: Gulf Book Centre, 2000).

Kelly, J. B. (John Barrett), "The Legal and Historical Basis of the British Position in the Persian Gulf," St Antony's Papers, 4: Middle Eastern Affairs, 1 (London: Chatto \& Windus, 1958), pp. 119-40.

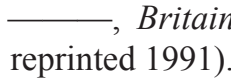

—, Arabia, the Gulf and the West (London: George Weidenfeld \& Nicolson, 1980).

Khalaf, Sulayman N., "Tribal Politics and Leadership in the Raqqa Region of Syria," MA thesis (American University of Beruit, Lebanon, 1975).

— , "Settlement of Violence in Bedouin Society," Ethnolog, 29 (1990), pp. 225-42.

Al Khalifa, Hamid bin Isa, First Light: Modern Bahrain and Its Heritage (London: Kegan 
Al Khalifa, Abdulla bin Khalid and Rice, Michael (eds.), Bahrain through the Ages: The History (London: Kegan Paul International, 1993).

Khuri, Fuad Ishaq, Tribe and State in Bahrain: The Transformation of Social and Political Authority in an Arab State (Chicago: University of Chicago Press, 1980).

Landen, Robert G., "The Arab Gulf in the Arab World 1800-1918," Arab Affairs, 1 (Summer 1986), pp. 57-71.

Lee, Air Marshall Sir David, Flight from the Middle East: A History of the Royal Air Force in the Arabian Peninsula and Adjacent Territories, 1945-1972 (London: H. M. Stationary Office, 1980).

Loewenstein, Andrew, “The Veiled Protectorate of Kowait”: Liberalized Imperialism and British Efforts to Influence Kuwaiti Domestic Policy during the Reign of Sheikh Ahmad al-Jaber, 1938-50,' Middle Eastern Studies, 36/2 (April 2000), pp. 101-23.

Louis, Wm. Roger, "The British Withdrawal from the Gulf, 1967-71," Journal of Imperial and Commonwealth History, 31/1 (2003), pp. 83-108.

Low, Lt Charles, History of the Indian Navy, 1613-1863, 2 vols. (London: Richard Bentley \& Son, 1877).

Moyse-Bartlett, Hubert, The Pirates of Trucial Oman (London: Macdonald, 1966).

al-Naqeeb, Khaldoun Hasan, Society and State in the Gulf and Arabian Peninsula: A Different Perspective, trans. L. M. Kenny (London: Routledge, 1990).

Newbury, Colin, Patrons, Clients and Empire: Chieftaincy and Over-rule in Asia, Africa and the Pacific (Oxford: Oxford University Press, 2003).

Onley, James, "The Politics of Protection in the Gulf: The Arab Rulers and the British Resident in the Nineteenth Century," New Arabian Studies, 6 (2004), pp. 30-92.

- "Britain's Native Agents in Arabia and Persia in the Nineteenth Century," Comparative Studies of South Asia, Africa, and the Middle East, 24/1 (2004), pp. 131-9.

—, "The Raj Reconsidered: British India's Informal Empire and Spheres of Influence in Asia and Africa," Asian Affairs, 40/1 (2009), pp. 44-62.

- The Arabian Frontier of the British Raj: Merchants, Rulers, and the British in the Nineteenth-Century Gulf(Oxford: Oxford University Press, 2007).

Palmer, Michael, Guardians of the Gulf: A History of America's Expanding Role in the Persian Gulf, 1883-1992 (New York: Free Press, 1992). 
Peterson, J. E. (John Everett), "Britain and the Oman War: An Arabian Entanglement," Asian Affairs, 63/3 (Oct. 1976), pp. 285-98.

_ , "Tribes and Politics in Eastern Arabia," Middle East Journal, 31/3 (1977), pp. 297-312.

— Defending Arabia (London: Croom Helm, 1986).

_ Oman's Insurgencies: The Sultanate's Struggle for Supremacy (London: Saqi, 2007).

Peterson, Tore, The Decline of the Anglo-American Middle East, 1961-1969: A Willing Retreat (Sussex: Academic Press, 2006).

Preston, Anthony and Major, John, Send a Gunboat! A Study of the Gunboat and Its Role in British Policy, 1854-1904 (London: Longmans, 1967).

Pridham, Brian, (ed.), The Arab Gulf and the West (London: Croom Helm, 1985). (ed.), The Arab Gulf and the Arab World (London: Croom Helm, 1988).

al-Qasimi, Sultan bin Muhammad, The Myth of Arab Piracy in the Gulf (London: Routledge, 1986).

al-Rasheed, Madawi, Politics in an Arabian Oasis: The Rashidis of Saudi Arabia (London: I.B. Tauris, 1991).

el-Rayyes, Riad, "Arab Nationalism in the Gulf," in Brian Pridham (ed.), The Arab Gulf and the Arab World (London: Croom Helm, 1988), pp. 67-94.

Risso [Dubuisson], Patricia, "Qasimi Piracy and the General Treaty of Peace (1820)," Arabian Studies, 4 (1978), pp. 47-57.

_ , "Cross-Cultural Perceptions of Piracy: Maritime Violence in the Western Indian Ocean and Persian Gulf Region during a Long Eighteenth Century," Journal of World History, 12 (2001), pp. 293-319.

Roberts, David, "The Consequences of the Exclusive Treaties: A British View," in Brian Pridham (ed.), The Arab Gulf and the West (London: Croom Helm, 1985), pp. 1-14.

Rosenfeld, Henry, "The Social Composition of the Military in the Process of State Formation in the Arabian Desert," Parts I \& II, The Journal of the Royal Anthropological Institute of Great Britain and Ireland, 95 (1965), pp. 75-86 and 174-94.

Saffoury, Lamia Y., "Britain's Withdrawal from the Persian Gulf: Decision and Background," MA thesis (American University of Beirut, 1970). 
al-Samarrai, Bashir, "Military Buildup and Political Instability in the Gulf, 1965-1974," PhD dissertation (University of Denver, 1978).

Sand, Peter, United States and Britain in Diego Garcia: The Future of a Controversial Base (Basingstoke: Palgrave, 2009).

Sato, Shohei, "Britain's Decision to Withdraw from the Persian Gulf, 1964-68: A Pattern and a Puzzle," Journal of Imperial and Commonwealth History, 37/1 (2009), pp. 99-117; Smith, Britain's Revival and Fall in the Gulf.

al-Sayegh, Fatma, "Imperial Air Communications and British Policy Changes in the Trucial States, 1929-1952," PhD thesis (University of Essex, 1990).

_- "Merchants' Role in a Changing Society: The Case of Dubai, 1900-90," Middle Eastern Studies, 34/1 (1998), pp. 87-102.

Scudder, Lewis III, The Arabian Mission's Story: In Search of Abraham's Other Son (Grand Rapids, MI: Wm. B. Eerdmans Publishing Company, 1998).

Smith, Simon C., Kuwait, 1950-1965: Britain, the al-Sabah, and Oil (Oxford: Oxford University Press, 2000).

_- "The Making of a Neo-Colony? Anglo-Kuwaiti Relations in the Era of Decolonization," Middle Eastern Studies, 37/1 (January 2001), pp. 159-72.

- Britain's Revival and Fall in the Gulf: Kuwait, Bahrain, Qatar, and the Trucial States, 1950-71 (London: RoutledgeCurzon, 2004).

Sridharan, K., A Maritime History of India, 2nd edn. (New Delhi: Ministry of Information and Broadcasting, 1982).

Sweet, Louise, "Pirates or Polities? Arab Societies of the Persian or Arabian Gulf, $18^{\text {th }}$ Century," Ethnohistory, 11/3 (1964), pp. 262-80.

Taryam, Abdullah Omran, The Establishment of the United Arab Emirates, 1950-85 (London: Croom Helm, 1987).

Tuson, Penelope, The Records of the British Residency and Agencies in the Persian Gulf. IOR R/15 (London: India Office Records, 1979).

Tuson, Penelope, "Some British Views of Bahrain: The Work of the Bombay Marine and Indian Navy, 1785-1863," in Abdulla bin Khalid Al Khalifa and Michael Rice (eds.), Bahrain through the Ages: The History (London: Kegan Paul International, 1993), pp. 525-47.

Vitalis, Robert, America's Kingdom: Mythmaking on the Saudi Oil Frontier (Stanford: 
Stanford University Press, 2007).

von Bismarck, Helene, "The Kuwait Crisis of 1961 and its Consequences for Great Britain's Persian Gulf Policy,” British Scholar, 2/1 (2009), pp. 75-96.

Watt, D.C., "The Decision to Withdraw from the Gulf," Political Quarterly, 39/3 (1968).

—_, "Britain and the Indian Ocean," Political Quarterly, 42/3 (1971).

Winkler, David, Amirs, Admirals, and Desert Sailors: Bahrain, the US Navy, and the Arabian Gulf (Annapolis: Naval Institute Press, 2007).

Wright, Sir Dennis, The English Amongst the Persians during the Qajar Period, 17871921 (London: Heinemann, 1977).

Yodfat, Aryeh, In the Direction of the Persian Gulf: The Soviet Union and the Persian Gulf(London: Frank Cass, 1977).

- The Soviet Union and the Arabian Peninsula: Soviet Policy towards the Persian Gulf and Arabia (London: Croom Helm, 1983).

Zahlan, Rosemarie Janet Said, The Origins of the United Arab Emirates: A Political and Social History (London: Macmillan, 1978).

- The Creation of Qatar (London: Croom Helm, 1979).

- "Shades of the Past: The Iraq-Kuwait Dispute, 1961," Journal of Social Affairs, 22/87 (2005), pp. 47-80. 



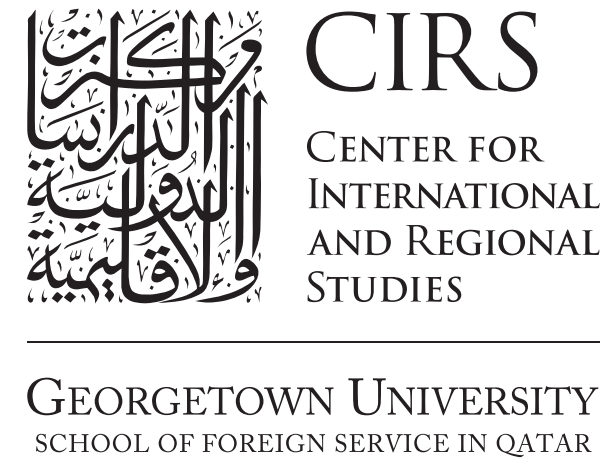

Center for International and Regional Studies Georgetown University School of Foreign Service in Qatar P.O. Box 23689

Doha, Qatar

http://cirs.georgetown.edu

Tel +9744578400

Fax +9744578401 


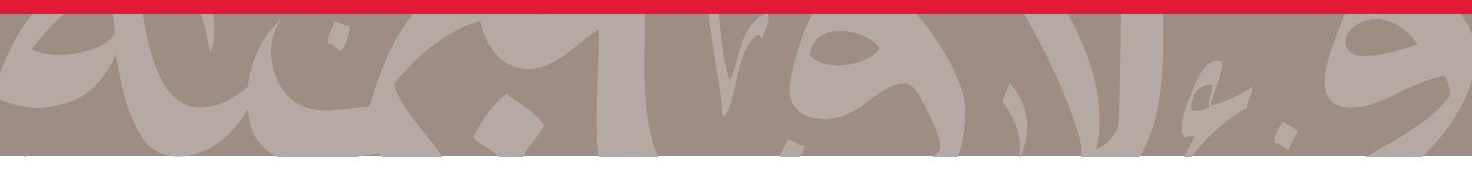

